\title{
Molecular Structure, Vibrational Spectral Investigations (FT-IR and FT-Raman), NLO, NBO, HOMO-LUMO, MEP Analysis of (E)-2-(3-pentyl-2,6-diphenylpiperidin-4- ylidene)-N-phenylhydrazinecarbothioamide Based on DFT and Molecular Docking Studies
}

\author{
Savithiri Sambandam 1,*(i) , Bharanidharan Sarangapani ${ }^{2(\mathbb{D})}$, Sugumar Paramasivam ${ }^{3(\mathbb{D})}$, Rajeevgandhi \\ Chinnaiyan 4 (D) \\ 1 Department of Chemistry, Karpagam Academy of Higher Education, Coimbatore - 641 021, India; \\ savithiri.chem@gmail.com (S.S.); \\ 2 Department of Physics, PRIST University, Puducherry - 605 007, India; bharani.dharan0@ gmail.com (B.S.); \\ 3 Department of Physics, Dhaanish Ahmed College of Engineering, Tambaram, Chennai - 601 301, Tamilnadu, India; \\ sugumar17283@gmail.com (S.P.); \\ 4 Department of Physics, Annamalai University, Annamalainagar - 608 002, Tamilnadu, India; rajeevphdphy@gmail.com \\ (R.C.); \\ * Correspondence: savithiri.chem@gmail.com;
}

Scopus Author ID 56294087000

Received: 5.11.2020; Revised: 12.12.2020; Accepted: 16.12.2020; Published: 18.12.2020

\begin{abstract}
The molecular spectroscopic investigations of (E)-2-(3-pentyl-2,6-diphenylpiperidin-4ylidene)- $N$-phenylhydrazine carbothioamide (3-PDPPPHC) are studied. The FT-IR and FT-Raman experimental spectra of the molecule have been recorded in the range of $4000-400 \mathrm{~cm}^{-1}$ and $4000-50$ $\mathrm{cm}^{-1}$, respectively. The molecular structure, fundamental vibrational frequencies, and intensities of the vibrational bands were interpreted to aid structure optimizations based on the density functional theory (DFT) method with B3LYP/6-311++G(d,p) level of basis set. The complete vibrational assignments of wavenumbers were made based on total energy distribution (TED). The calculations' results were applied to the title compound's simulated spectra, which show good agreement with observed spectra. The dipole moment, polarizability, and first hyperpolarizability values were also computed. The stability of the molecule analyzing from hyper-conjugative interaction and charge delocalization of the title compounds were studied by NBO analysis. Frontier molecular orbitals (FMOs), molecular electrostatic potential (MEP), and thermodynamic properties were performed. Mulliken charges of the title molecule were also calculated and interpreted. The thermodynamic properties such as heat capacity, entropy, and enthalpy of the title compound were calculated at different gas-phase temperatures. To establish information about the interactions between protein and this novel compound theoretically, docking studies were carried out in detail.
\end{abstract}

Keywords: FT-IR; FT-Raman; NLO; NBO; FMO;molecular docking.

(c) 2020 by the authors. This article is an open-access article distributed under the terms and conditions of the Creative Commons Attribution (CC BY) license (https://creativecommons.org/licenses/by/4.0/).

\section{Introduction}

Nitrogen-containing heterocyclic compounds, especially piperidones, gain considerable importance owing to their varied biological properties. Thiosemicarbazones show very interesting and important biological activity in pharmaceutical and industrial aspects as antibacterial [1], antifungal [2], antimalarial [3,4] antioxidant activity [5,6] anticancer [7-9] 
and anticonvulsant [10] antimycobacterial activity [11], antiproliferative activity [12,13], Toxicity [14], cytotoxicity [15] and several biological activity of thiosemicarbazones [16-21]. However, little is known about piperidine-4-ones substituted with a thiosemicarbazone moiety possessing potential pharmacological activities such as antiviral and antiprotozoal activities [22-25]. A few semicarbazones, just as their sulfur analogs and their derivatives, have proved their efficiency and efficacy in combating various diseases [26]. Theoretical investigations of thiosemicarbazones were reported by DFT method [27-29]. NLO materials play a vital role in various fields such as fiber optics communications and optical signal processing. In the last two decades, intensive research has shown that organic crystals also exhibit non-linear optical efficiencies of greater magnitude than inorganic materials. Semicarbazones and thiosemicarbazone of substituted heterocyclic organic compounds, ketones, and acetophenones were accounted for to be potential organic NLO [30-32] materials. The FT-IR and FT-Raman spectra joined with quantum chemical computations have been recently used as an effective tool in the vibrational analysis of drug molecules [33], biological compounds [34] and natural products [35], since FT-Raman spectra and processed outcomes can help unambiguous distinguishing proof of the vibrational modes as well as the bonding and structural features of organic molecular systems. Both the IR and Raman spectroscopic investigations have been used to obtain the structural information on molecules. The present study aimed to investigate the molecular structural properties, vibrational and energetic data of 3-PDPPPHC, in the gas phase, due to its pharmaceutical importance. The ground and the excited state properties of the title molecule are B3LYP/6-311++G(d,p) hybrid functional is used for density functional theory (DFT) calculation. As vibrational and electronic spectroscopic studies provide very useful information about the structure and conformation of the molecules if utilized in collaboration with quantum chemical calculations, to obtain a complete description of molecular dynamics, vibrational wavenumber calculation, and the normal mode analysis has been administered at the DFT theory. The investigation of geometry, dipole moment, polarizability, first static hyperpolarizability, along with the molecular electrostatic potential surface will lead to a better understanding of the structural and spectral characteristics of the compound chosen for the study.

\section{Materials and Methods}

\subsection{Experimental details.}

2.1.1. Synthesis procedure.

(E)-2-(3-pentyl-2,6-diphenylpiperidin-4-ylidene)-N-phenylhydrazinecarbothioamide was synthesized by subsequent the procedure described in the literature [36]. The spectral data are reliable with the reported values [36].

\subsubsection{FT-IR and FT-Raman spectra details.}

The FT-IR spectrum of the synthesized 3-PDPPPHC was measured in the range 4000$400 \mathrm{~cm}^{-1}$ in AVATAR-330 FT-IR spectrometer (Thermo Nicolet) using KBr (pellet form) in the Department of Chemistry, Annamalai University, Chidambaram, Tamilnadu. FT-Raman spectrum was observed using laser source $\mathrm{Nd}$ :YAG $1064 \mathrm{~nm}$ as excitation wavelength in the region 4000-50 $\mathrm{cm}^{-1}$ on Bruker IFS 66v spectrophotometer equipped with an FRA 106 FT- 
Raman module accessory and at a spectral resolution of $4 \mathrm{~cm}^{-1}$. The FT-Raman spectrum was recorded at SAIF Laboratory, IIT Madras.

\subsection{Computational details.}

\subsubsection{DFT Calculation.}

The DFT method performed the entire quantum chemical calculations using the Gaussian 09W program package [37]. The optimized structural bond parameters and fundamental vibrational frequencies were calculated. The vibrational frequency assignments were made with a high degree of accuracy. The TED analysis was made using the VEDA4 program [38]. The NBO calculations were performed using NBO 3.1 program [39] as implemented in the Gaussian 09W [37] package. The DOS spectrum was drawn with the help of the Gauss sum 3.0 program [40]. In the present work, the DFT approach with 6-311++G(d,p) as a basis for computation of molecular structure, vibrational frequencies, and energies of optimized structures was utilized. The Bond parameters, NLO, NBO, HOMO-LUMO, Mulliken atomic charges, MEP, and thermodynamic parameters were calculated using the B3LYP/6-311++G(d,p) basis set.

\subsubsection{Molecular docking.}

Metallo- $\beta$-lactamases (MBLs) one of the most significant and boundless components of protection from $\beta$-lactam anti-microbials, against which no clinically helpful inhibitors are as of now accessible. We report thus a structure-based high-throughput docking (HTD) crusade on clinically-applicable procured MBLs.

The study's objective is to demonstrate that piperidone derivatives bind to betalactamase enzymes and evaluate whether these molecules can be used as a potential drug. The structural information and the data for the target were collected from the "Protein Data Bank" (PDB). The PDB ID: 1EVE [41] was used as the template for our studies. They were predicting the most likely conformation of how a ligand will bind to a macromolecule and some relevant residues of the protein considered flexible during the docking simulation. Basic potential parameters fit protein-ligand binding, and data scoring functions are comparable with new hydrogen bonding term and new charge schemes.

Docking calculations were carried out on the Beta-lactamase enzyme protein model [42]. Essential hydrogen atoms, Kollman united atom type charges, and solvation parameters were added with AutoDock tools' aid [43].

\section{Results and Discussion}

\subsection{Geometrical parameters.}

The optimized molecular structure of 3-PDPPPHC with atom numbering scheme is shown in Fig. 1. The optimized structural parameters, such as bond lengths, bond angles, and dihedral angles, were determined at the DFT/B3LYP/6-311++G(d,p) basis set. The values are listed in Table 1. In this study, the C-C, C-N, C=S, N-H, and C-H bond distances are calculated and compared with structurally related molecules [44]. The calculated C-C bond distances in the heterocyclic ring are in the range of $1.573-1.518 \AA$, compared with the reported DFT value $(1.585-1.508 \AA$ ) [44]. In addition, the DFT value of C-C bond lengths in phenyl also rings agreement with literature values [44]. The $\mathrm{C}=\mathrm{S}$ bond length is calculated at $1.662 \AA$ and 
is also related to reported data $1.681 \AA$. The $\mathrm{C}-\mathrm{N}$ bond lengths in the range $1.470-1.380 \AA$ by the B3LYP method, respectively, are in agreement with the reported values $1.471-1.288 \AA$ [44]. The optimized N-H bond lengths fall in the range $1.017-1.013 \AA$ by B3LYP method with 6-311++G(d,p) basis set and comparing these values with literature value $1.000-0.993$ $\AA$, respectively. Also, the bond angles of C2-C1-N9 (107.96 $)$ and C4-C5-N9 (108.32 $)$, which are calculated at DFT/B3LYP/6-311++G(d,p) basis set and are form to decrease from $120^{\circ}$. This is due to the phenyl group's substitution in connection with $\mathrm{C} 1$ and $\mathrm{C} 5$ carbon atoms in the piperidone ring. The piperidone ring essentially adopts chair conformation with all substituents equatorial as evident from the torsional angles N9-C1-C2 $-\mathrm{C} 3=-58.88$ and N9C5-C4-C3 $=55.76$ by B3LYP, respectively. In the optimized molecular structure, the thiosemicarbazone analog is nearly planar with the dihedral angle N26-N27-C32-N28 $\left(176.62^{\circ}\right)$ adopts an $E$-configuration concerning the C3-N26 bond. The calculated values are comparable with reported values [44].



Figure 1. The optimized molecular structure of 3-PDPPPHC.

Table 1. The optimized bond parameters of 3-PDPPPHC.

\begin{tabular}{|c|c|c|c|c|c|}
\hline Bond Lengths (̊̊) & DFT & Bond Angles $\left({ }^{\circ}\right)$ & DFT & Dihedral Angles $\left({ }^{\circ}\right)$ & DFT \\
\hline $\mathrm{C} 1-\mathrm{C} 2$ & 1.573 & C2-C1-N9 & 107.96 & N9-C1-C2-C3 & -58.8837 \\
\hline C1-N9 & 1.470 & C2-C1-H35 & 106.62 & N9-C1-C2-H6 & 51.5304 \\
\hline $\mathrm{C} 2-\mathrm{C} 3$ & 1.530 & $\mathrm{C} 2-\mathrm{C} 1-\mathrm{C} 36$ & 113.40 & N9-C1-C2-C11 & 166.6641 \\
\hline $\mathrm{C} 2-\mathrm{C} 11$ & 1.540 & N9-C1-H35 & 112.05 & H35-C1-C2-C3 & 61.6846 \\
\hline $\mathrm{C} 3-\mathrm{C} 4$ & 1.511 & N9-C1-C36 & 109.02 & H35-C1-C2-H6 & 172.0987 \\
\hline C3-N26 & 1.286 & H35-C1-C36 & 107.84 & H35-C1-C2-C11 & -72.7675 \\
\hline $\mathrm{C} 4-\mathrm{C} 5$ & 1.551 & $\mathrm{C} 1-\mathrm{C} 2-\mathrm{C} 3$ & 105.63 & C36-C1-C2-C3 & -179.791 \\
\hline $\mathrm{C} 4-\mathrm{H} 7$ & 1.097 & C1-C2-H6 & 104.44 & $\mathrm{C} 36-\mathrm{C} 1-\mathrm{C} 2-\mathrm{H} 6$ & -69.3772 \\
\hline C4-H8 & 1.091 & C1-C2-C11 & 114.25 & C36-C1-C2-C11 & 45.7565 \\
\hline C5-N9 & 1.468 & C3-C2-H6 & 104.96 & C2-C1-N9-C5 & 61.2724 \\
\hline C5-H34 & 1.105 & C3-C2-C11 & 120.28 & C2-C1-N9-H10 & -174.666 \\
\hline C5-C46 & 1.518 & H6-C2-C11 & 105.82 & H35-C1-N9-C5 & -55.8321 \\
\hline N9-H10 & 1.017 & $\mathrm{C} 2-\mathrm{C} 3-\mathrm{C} 4$ & 111.64 & H35-C1-N9-H10 & 68.2296 \\
\hline C11-H12 & 1.095 & C2-C3-N26 & 133.27 & C36-C1-N9-C5 & -175.125 \\
\hline C11-H13 & 1.100 & C4-C3-N26 & 114.36 & C36-C1-N9-H10 & -51.0632 \\
\hline C11-C14 & 1.539 & $\mathrm{C} 3-\mathrm{C} 4-\mathrm{C} 5$ & 108.36 & C2-C1-C36-C37 & 72.8434 \\
\hline C14-H15 & 1.098 & C3-C4-H7 & 111.30 & C2-C1-C36-C38 & -107.06 \\
\hline C14-C16 & 1.538 & $\mathrm{C} 3-\mathrm{C} 4-\mathrm{H} 8$ & 109.66 & N9-C1-C36-C37 & -47.4609 \\
\hline C14-H33 & 1.098 & C5-C4-H7 & 108.45 & N9-C1-C36-C38 & 132.6359 \\
\hline C16-H17 & 1.098 & $\mathrm{C} 5-\mathrm{C} 4-\mathrm{H} 8$ & 109.90 & H35-C1-C36-C37 & -169.34 \\
\hline C16-H18 & 1.099 & $\mathrm{H} 7-\mathrm{C} 4-\mathrm{H} 8$ & 109.15 & H35-C1-C36-C38 & 10.7569 \\
\hline C16-C19 & 1.536 & C4-C5-N9 & 108.32 & C1-C2-C3-C4 & 62.4067 \\
\hline C19-H20 & 1.099 & C4-C5-H34 & 106.17 & C1-C2-C3-N26 & -107.045 \\
\hline C19-H21 & 1.100 & C4-C5-C46 & 111.85 & H6-C2-C3-C4 & -47.6392 \\
\hline
\end{tabular}




\begin{tabular}{|c|c|c|c|c|c|}
\hline Bond Lengths $(\AA)$ & DFT & Bond Angles $\left({ }^{\circ}\right)$ & DFT & Dihedral Angles $\left({ }^{\circ}\right)$ & DFT \\
\hline C19-C22 & 1.532 & N9-C5-H34 & 111.58 & H6-C2-C3-N26 & 142.9095 \\
\hline $\mathrm{C} 22-\mathrm{H} 23$ & 1.095 & N9-C5-C46 & 110.79 & $\mathrm{C} 11-\mathrm{C} 2-\mathrm{C} 3-\mathrm{C} 4$ & -166.505 \\
\hline $\mathrm{C} 22-\mathrm{H} 24$ & 1.095 & H34-C5-C46 & 108.07 & C11-C2-C3-N26 & 24.0441 \\
\hline $\mathrm{C} 22-\mathrm{H} 25$ & 1.095 & C1-N9-C5 & 115.41 & C1-C2-C11-H12 & -53.1277 \\
\hline N26-N27 & 1.359 & C1-N9-H10 & 109.25 & C1-C2-C11-H13 & 60.1182 \\
\hline N27-H30 & 1.013 & C5-N9-H10 & 109.64 & C1-C2-C11-C14 & -172.12 \\
\hline $\mathrm{N} 27-\mathrm{C} 32$ & 1.388 & C2-C11-H12 & 107.16 & C3-C2-C11-H12 & 179.6308 \\
\hline $\mathrm{N} 28-\mathrm{H} 29$ & 1.013 & $\mathrm{C} 2-\mathrm{C} 11-\mathrm{H} 13$ & 111.80 & C3-C2-C11-H13 & -67.1233 \\
\hline N28-C32 & 1.380 & C2-C11-C14 & 113.46 & C3-C2-C11-C14 & 60.6383 \\
\hline $\mathrm{N} 28-\mathrm{C} 58$ & 1.413 & H12-C11-H13 & 103.92 & H6-C2-C11-H12 & 61.1982 \\
\hline S31-C32 & 1.662 & $\mathrm{H} 12-\mathrm{C} 11-\mathrm{C} 14$ & 107.90 & H6-C2-C11-H13 & 174.444 \\
\hline S31-H64 & 2.683 & H13-C11-C14 & 111.95 & H6-C2-C11-C14 & -57.7944 \\
\hline C36-C37 & 1.403 & C11-C14-H15 & 110.84 & C2-C3-C4-C5 & -61.5417 \\
\hline C36-C38 & 1.400 & C11-C14-H16 & 114.26 & C2-C3-C4-H7 & 57.6231 \\
\hline C37-C39 & 1.394 & C11-C14-H33 & 107.50 & C2-C3-C4-H8 & 178.503 \\
\hline C38-C41 & 1.396 & $\mathrm{H} 15-\mathrm{C} 14-\mathrm{C} 16$ & 109.44 & N26-C3-C4-C5 & 110.0442 \\
\hline C39-C43 & 1.397 & H15-C14-H33 & 105.71 & N26-C3-C4-H7 & -130.791 \\
\hline $\mathrm{C} 41-\mathrm{C} 43$ & 1.395 & C16-C14-H33 & 108.70 & N26-C3-C4-H8 & -9.911 \\
\hline $\mathrm{C} 46-\mathrm{C} 47$ & 1.401 & C14-C16-H17 & 108.68 & C2-C3-N26-N27 & -3.8249 \\
\hline $\mathrm{C} 46-\mathrm{C} 48$ & 1.400 & C14-C16-H18 & 109.47 & C4-C3-N26-N27 & -173.059 \\
\hline C47-C49 & 1.395 & C14-C16-C19 & 114.89 & C3-C4-C5-N9 & 55.7579 \\
\hline C48-C51 & 1.395 & H17-C16-H18 & 106.01 & C3-C4-C5-H34 & -64.2032 \\
\hline C49-C53 & 1.396 & H17-C16-C19 & 108.23 & C3-C4-C5-C46 & 178.142 \\
\hline C51-C53 & 1.396 & H18-C16-C19 & 109.18 & H7-C4-C5-N9 & -65.188 \\
\hline C58-C59 & 1.404 & C16-C19-H20 & 110.08 & H7-C4-C5-H34 & 174.8509 \\
\hline C58-C60 & 1.402 & C16-C19-H21 & 108.50 & H7-C4-C5-C46 & 57.1961 \\
\hline C59-C61 & 1.392 & $\mathrm{C} 16-\mathrm{C} 19-\mathrm{C} 22$ & 113.13 & H8-C4-C5-N9 & 175.5646 \\
\hline C60-C63 & 1.394 & $\mathrm{H} 20-\mathrm{C} 19-\mathrm{H} 21$ & 106.93 & H8-C4-C5-H34 & 55.6035 \\
\hline C61-C65 & 1.395 & $\mathrm{H} 20-\mathrm{C} 19-\mathrm{C} 22$ & 108.84 & H8-C4-C5-C46 & -62.0513 \\
\hline C63-C65 & 1.396 & $\mathrm{H} 21-\mathrm{C} 19-\mathrm{C} 22$ & 109.18 & C4-C5-N9-C1 & -58.9801 \\
\hline
\end{tabular}

\subsection{Vibrational assignments.}

The 3-PDPPPHC molecule has 68 atoms and belongs to $\mathrm{C}_{1}$ point group symmetry; hence 198 normal modes of vibrations are possible and are distributed as $\Gamma_{\text {vib }}=133 \mathrm{~A}^{\prime}+65 \mathrm{~A}^{\prime \prime}$. All the vibrations are active in both IR and Raman absorption. With the exclusion of the anharmonicity factor and the basis set used, certain theoretical frequencies are not matched with experimental values. Hence, in this study, a linear scaling procedure is used to scale down the harmonic frequencies; we have followed the uniform scaling factor 0.9608 for DFT method [45]. After scaling the calculated frequencies, the observed values' deviation is less than 10 $\mathrm{cm}^{-1}$ with few exceptions. The scaled frequencies, observed frequencies (FT-IR, FT-Raman) with their intensities, force constants, reduced masses, and proposed vibrational assignments along with TED values are summarized in Table 2 . The simulated, observed FT-IR and FTRaman spectra are shown in Figs. $2 \& 3$, respectively.

\subsubsection{N-H vibrations.}

In general, the $v_{\mathrm{N}-\mathrm{H}}$ modes are expected to occur in the region $3200-3400 \mathrm{~cm}^{-1}$ [46]. In agreement with these observations, the harmonic bands at $3435,3421 \& 3383 \mathrm{~cm}^{-1}$ (mode nos: $1,2 \& 3)$ is designated as $v_{\mathrm{N}-\mathrm{H}}$ mode, while the experimental FT-IR bands at $3433,3374 \&$ $3308 \mathrm{~cm}^{-1}$ and $3434,3375 \& 3310 \mathrm{~cm}^{-1}$ in FT-Raman spectrum and is a pure mode (TED: 92, $92 \& 99 \%$ ), respectively. The harmonic wavenumber for $\beta_{\mathrm{NNH}} \& \tau_{\mathrm{HNNC}}$ lies at $1516 / 421 \mathrm{~cm}^{-1}$, respectively having considerable TED value $(25 \& 56 \%)$ and its corresponding mode nos: 48 $\&$ 161. On comparing the present investigation with the above literature, the lowering/increasing of wavenumbers may be due to the delocalization of electrons in the piperidone ring. 


\subsubsection{Aromatic C-H vibrations.}

Aromatic compounds commonly exhibit multiple bands in the region of $3000-3100 \mathrm{~cm}^{-}$ ${ }^{1}$ due to $\mathrm{CH}$ stretching vibrations. In 3-PDPPPHC the $\mathrm{C}-\mathrm{H}$ bands were observed at $3083 \mathrm{~cm}^{-1}$ in FT-Raman and $3084 \mathrm{~cm}^{-1}$ in FT-IR spectra, while the calculated frequencies are in the range of $3084 \mathrm{~cm}^{-1}$ (mode no: 5). In addition, C-H vibrations are observed in the region of 3057 , $3030,2949,2930 \& 2860 \mathrm{~cm}^{-1}$ in FT-Raman spectrum and 3058, 3028, 2948, $2925 \& 2855$ $\mathrm{cm}^{-1}$ in FT-IR spectrum and the corresponding harmonic values lies at 3057, 3042, 2950, 2934 $\& 2882 \mathrm{~cm}^{-1}$, respectively (mode nos: $14,18,23,25 \& 32$ ). These assignments are well support by their TED value.

In general, the $\mathrm{C}-\mathrm{H}$ in-plane bending vibrations normally occur as a number of strong and weak bands in the region 1000-1400 $\mathrm{cm}^{-1}$. Similarly, the C-H out-of-plane bending vibrations are expected in the region of $809-950 \mathrm{~cm}^{-1}$ [47]. In 3-PDPPPHC the C-H in-plane bending vibrations are assigned at 1444, $1382 \& 1325 \mathrm{~cm}^{-1}$ in FT-IR spectrum and 1445,1385 $\& 1328 \mathrm{~cm}^{-1}$ in FT-Raman spectrum and their related harmonic frequencies are: $1446,1385 \&$ $1328 \mathrm{~cm}^{-1}$ (mode nos: 51, 57, 63). The $\mathrm{C}$-H out-of-plane bending vibration of 3-PDPPPHC molecule was observed at $828,807 \mathrm{~cm}^{-1}$ in the FT-IR spectrum. In contrast, the Raman bands are observed at $829,806 \mathrm{~cm}^{-1}$, respectively. The calculated frequencies are $832 \& 806 \mathrm{~cm}-1$ (mode nos: 128, 130) also find support from TED values for the same mode.

\subsubsection{C-C vibrations.}

In General, the $\mathrm{C}=\mathrm{C}$ and $\mathrm{C}-\mathrm{C}$ stretching vibrations are usually occur in the region 1450 $1625 \mathrm{~cm}^{-1}$ [48]. Hence in the present investigation, the FT-IR band identified at $1444 \mathrm{~cm}^{-1}$ and FT-Raman band at $1445 \mathrm{~cm}^{-1}$ is assigned to C-C stretching vibration of 3-PDPPPHC in mode no: 51 TED 25\%. The $\beta$ CCH vibrations are assigned at $1068 \mathrm{~cm}^{-1}$ in FT-IR and $1030 \mathrm{~cm}^{-1}$ in FTRaman spectrum. Its corresponding harmonic values lie at $1036 \mathrm{~cm}^{-1}$ with TED $45 \%$ (mode no: 98). Similarly, $\Gamma_{\mathrm{HCCH}}$ mode ascribed to wavenumbers at $980 \mathrm{~cm}^{-1}$ (mode no: 116 ). These assignments have considerable TED values and compare with experimental values (FT-IR/941 and FT-Raman/940 $\mathrm{cm}^{-1}$ ), respectively. These results conclude that the positive/negative deviation of wavenumbers may be due to the piperidone ring's resonance.

\subsection{4. $\mathrm{C}=\mathrm{N}, \mathrm{C}-\mathrm{N}$, and $\mathrm{N}-\mathrm{N}$ vibrations.}

In general, the identification of $\mathrm{C}=\mathrm{N}$ and $\mathrm{C}-\mathrm{N}$ vibrations was very difficult, as the mixing of several bands become possible in this region. Silverstain and Webster [49] assigned the C-N stretching absorption in the region 1689-1417 $\mathrm{cm}^{-1}$ for aromatic amines. In 3PDPPPHC, the $\mathrm{C}=\mathrm{N}$ stretching band is found at $1594 \mathrm{~cm}^{-1}$ in FT-IR and $1595 \mathrm{~cm}^{-1}$ in Raman band. The computed wavenumbers $1646 \mathrm{~cm}^{-1}$ (mode no: 35 ) are assigned with TED value of $78 \%$. From Table 2, C-N stretching vibration is observed at $1535 \mathrm{~cm}^{-1}$ and $1537 \mathrm{~cm}^{-1}$ in FT-IR \& FT-Raman bands, respectively. The DFT calculation gave bands at $1576 \mathrm{~cm}^{-1}$ (mode no: 41 ). The in-plane $\left(\beta_{\mathrm{HNC}}:\right.$ FT-IR/1382 \& FT-Raman/1385 $\left.\mathrm{cm}^{-1}\right)$ and out-of-plane bending $\Gamma_{\mathrm{CCNH}}$ appeared at 1300 (FT-IR) and $1299 \mathrm{~cm}^{-1}$ (FT-Raman), this vibration shows in good agreement with the theoretical frequency of $1359 \& 1320 \mathrm{~cm}^{-1}$ (mode nos: $59 \&$ 65) by B3LYP/6$311++\mathrm{G}(\mathrm{d}, \mathrm{p})$ method. The theoretically computed $\mathrm{N}-\mathrm{N}$ stretching has been calculated at 1115 $\mathrm{cm}^{-1}$, which mode no. 93 (TED: 25\%) is in agreement with FT-IR value $1109 \mathrm{~cm}^{-1}$ and FTRaman $1112 \mathrm{~cm}^{-1}$, respectively. 


\subsection{5. $\mathrm{C}=\mathrm{S}$ vibrations.}

In this study, the mode no: 139 are ascribed to $v_{\mathrm{C}=\mathrm{S}}$ vibrations at $698 \mathrm{~cm}^{-1}$ in FT-IR band and $v_{\mathrm{C}=\mathrm{S}} / 699 \mathrm{~cm}^{-1}$ in FT-Raman band and its corresponding harmonic wavenumbers at $672 \mathrm{~cm}^{-}$

${ }^{1}$ to support from TED value (>23\%), respectively following the literature [50]. The harmonic frequencies 650 and $573 \mathrm{~cm}^{-1}$ (mode nos: 144, 152) are designated as $\beta_{\mathrm{CS}}$ (FT-IR: 645 \& FTRaman: $648 \mathrm{~cm}^{-1}$ ) and $\Gamma_{\mathrm{CS}}$ modes (FT-IR: $570 \&$ FT-Raman: $572 \mathrm{~cm}^{-1}$ ), respectively. These assignments are found support from TED values $>20 \%$. It should be discussed here that the present assignment $v_{\mathrm{C}=\mathrm{S}}$ vibrations have deviated from the literature, which may be due to unhybridized orbital of sulfur-containing two electrons form part of the delocalized electron cloud by lateral overlapping with an unhybridized orbital of carbon atoms. Electron pair in one of the hybrid orbital remains shared.

\subsection{6. $\mathrm{CH}_{3}$ and $\mathrm{CH}_{2}$ group vibrations.}

Generally, the C-H stretching in alkanes occurs at lower frequencies than those of the aromatic ring (3150-3050 $\left.\mathrm{cm}^{-1}\right)$. The $\mathrm{CH}_{3}$ stretching is expected at $2980-2870 \mathrm{~cm}^{-1}$ [51], and usually, the bands are weak. In the present study, the 3-PDPPPHC possesses methyl $\left(\mathrm{CH}_{3}\right)$ and methylene $\left(\mathrm{CH}_{2}\right)$ groups. Methyl group symmetric stretching appeared at $3028 \mathrm{~cm}^{-1}$ in FT-IR band and at $3030 \mathrm{~cm}^{-1}$ in FT-Raman spectrum agree with the theoretical values of $3042 \mathrm{~cm}^{-1}$ (mode no: 18 by B3LYP/6-311++G(d,p) method and it has considerable TED (63\%) value.

The experimental vibration bands at $1444 \mathrm{~cm}^{-1}$ (FT-IR) and $1445 \mathrm{~cm}^{-1}$ (FT-Raman) are assigned to $\mathrm{CH}_{2}$ vibrations. The DFT value lies in the range $1446 \mathrm{~cm}^{-1}$ (mode no: 51 ) by the B3LYP method, respectively. The out-of-plane bending mode, such as wagging and twisting modes of $\mathrm{CH}_{2}$ group, were observed at 1300, $1269 \mathrm{~cm}^{-1}$ (FT-IR) and 1299, $1268 \mathrm{~cm}^{-1}$ (FTRaman). The DFT calculation gave the bands at 1374 and $1322 \mathrm{~cm}^{-1}$ (mode nos: $65 \& 74$ ). The twisting and torsion modes of methyl vibrations are identified below $500 \mathrm{~cm}^{-1}$ and are supported by the harmonic value with TED distribution.

\subsection{Non-linear optical property.}

The NLO activity provides the key functions for frequency shifting, optical modulation, optical switching, and optical logic for the developing technologies in areas such as communication, signal processing, and optical inter-connections [52]. NLO describes the behavior of media. The dielectric polarizability ' $P$ ' responds nonlinearly to the electric field $E$ of the light. In this study, the polarizability and hyperpolarizability values are calculated by DFT/6-311++G(d,p) basis set. The polarizability $\left(\alpha_{0}=0.32671 \times 10^{-30} \mathrm{esu}\right)$ and first-order hyperpolarizability $\left(\beta_{0}=9.52518 \times 10^{-30} \mathrm{esu}\right)$ are calculated and listed in Table 3 . The first order hyperpolarizability $\beta_{0}$ value is twenty-six times greater than that of urea. Hence, the title molecule possesses good NLO activity.

\subsection{Natural bond orbital analysis.}

NBO analysis is an essential tool for studying intra- and inter-molecular bonding interactions and a convenient basis for investigating charge transfer or conjugative interaction in molecular systems. Some orbitals are electron donors. Some are acceptors; the energy difference between bonding and anti-bonding orbitals makes the molecule susceptible to interactions [53]. The interactions result in a loss of occupancy from the localized NBO of the 
idealized Lewis structure into an empty non-Lewis orbital. For each donor (i) and acceptor (j), the stabilization energy $E^{(2)}$ associated with the delocalization $i, j$ is estimated as

$$
E^{(2)}=\Delta E_{i j}=q_{i} \frac{F(i, j)^{2}}{\varepsilon_{j}-\varepsilon_{i}}
$$

Where $q_{i}$ is the donor orbital occupancy, $\varepsilon_{i}$ and $\varepsilon_{j}$ are diagonal elements. F(i,j) is the offdiagonal NBO Fock matrix element. The larger the energy difference $\mathrm{E}^{(2)}$ value, the more intensive the interaction is, i.e., more is donating tendency of an electron from one orbital. More is the accepting tendency of another orbital, which makes the interaction between them stronger. The analysis of the various donors and acceptors indicate that there are only two types of donors $\sigma \& \pi$, and two types of acceptors $\sigma^{*} \& \pi^{*}$, respectively. Comparable with $\sigma-\sigma^{*}, \pi$ $\pi^{*}$ transfer more energies in the present system.

The $\mathrm{E}^{(2)}$ energy values and types of the transition are shown in Table 4. The hyperconjugative interactions $\pi(\mathrm{C} 37-\mathrm{C} 39) \rightarrow \pi^{*}(\mathrm{C} 36-\mathrm{C} 38), \pi(\mathrm{C} 41-\mathrm{C} 43) \rightarrow \pi^{*}(\mathrm{C} 51-\mathrm{C} 53)$ and $\pi(\mathrm{C} 47-\mathrm{C} 49) \rightarrow \pi^{*}(\mathrm{C} 46-\mathrm{C} 48)$ transfer more stabilization energy: $86.94,87.11$ and $87.03 \mathrm{KJ} / \mathrm{mol}$ to the molecular system. In 3-PDPPPHC, the lone pair of sulfur and nitrogen atoms play a great role, i.e., the S31, N28, and N27 atoms transfer maximum energy 55.48, 224.26, and 238.28 $\mathrm{KJ} / \mathrm{mol}$ to (N27-C32, (CS31-C32) \& (S31-C32) bonds, respectively. Also, the $\pi^{*}-\pi^{*}$ bond also transfers more energies to its anti-bonding orbitals. The maximum hyperconjugative $\mathrm{E}^{(2)}$ energy is exhibited during the intermolecular interaction, which leads the molecule towards medicinal and biological applications [53].

\subsection{HOMO-LUMO analysis.}

The HOMO and the LUMO are named as frontier molecular orbitals (FMOs). The FMOs play an important role in the optical and electric properties and quantum chemistry. The HOMO-LUMO orbitals of 3-PDPPPHC molecule are calculated in the gas phase using the DFT method with B3LYP/6-311++G(d,p) Fig. 4. The green and red colors represent the positive phase and negative phase, respectively. It is clear from the figure that the HOMO is located over thiosemicarbazone moiety, and LUMO is located over the entire molecule except for $\mathrm{CH}_{2}$ and $\mathrm{CH}_{3}$ groups. The calculated energy values of HOMO, LUMO and HUMO-1, LUMO+1 are $-5.249 \mathrm{eV},-0.951 \mathrm{eV}$ and $-5.527 \mathrm{eV},-0.368 \mathrm{eV}$, respectively. The energy gap value between the HOMO and LUMO is $4.298 \mathrm{eV}$, and HOMO- 1 and LUMO+1 is $5.159 \mathrm{eV}$, respectively. The energy values of HOMO ( $\pi$-donor) and LUMO ( $\pi$-acceptor) and their energy gap reflect the molecule's chemical activity. The physicochemical properties such as Ionization potential (IP), Electron affinity (EA), electronegativity $(\chi)$, hardness ( $\eta$ ) and Electrophilicity index $(\omega)$ are deduced from ionization potential and electron affinity values [53] using the following equations:

$$
\begin{aligned}
& \text { Electronegativity }(\chi)=-\frac{I P+E A}{2} \\
& \text { Chemical hardness }(\mu)=-\frac{I P-E A}{2} \quad \text { and } \\
& \text { Electrophilicity index }(\omega)=\frac{x 2}{2 \eta}
\end{aligned}
$$

The energy values of highest occupied molecular orbital (HOMO)-Lowest unoccupied molecular orbital (LUMO), energy gap, electron affinity, electrophilicity index, chemical potential, and hardness of the title molecule are listed in Table 5. 


\subsection{Density of states.}

The density of states (DOS) spectrum for 3-PDPPPHC was obtained using Gauss Sum 3.0 program [40] and is shown in Fig. 5. The spectrum is used to explain the contribution of electrons to the conduction and valence band. The spectrum gives an idea about how many states are available at certain energy states. The lines at the starting end of the plot's energy axis, from $-20 \mathrm{eV}$ to $-5 \mathrm{eV}$, are called filled orbital, and from $-5 \mathrm{eV}$ to $0 \mathrm{eV}$, they are called a virtual orbital. The virtual orbital is not occupied and is also called an acceptor orbital. In contrast, the filled orbital is called the donor orbital.

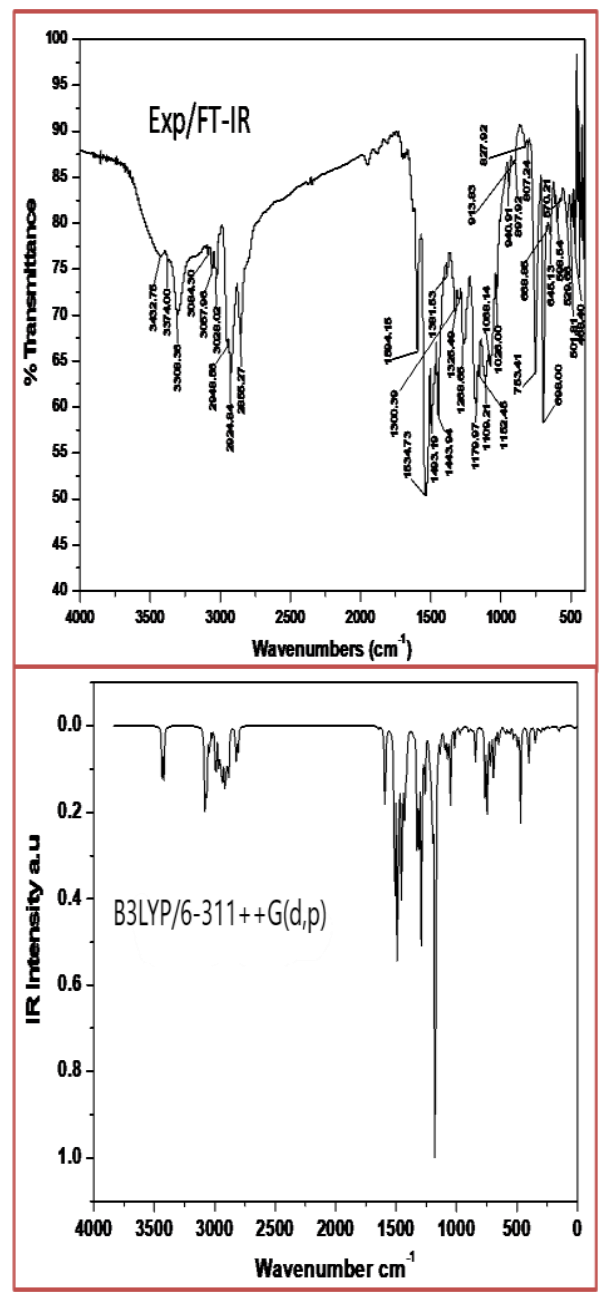

Figure 2. The theoretical and experimental FT-IR spectra of 3-PDPPPHC.

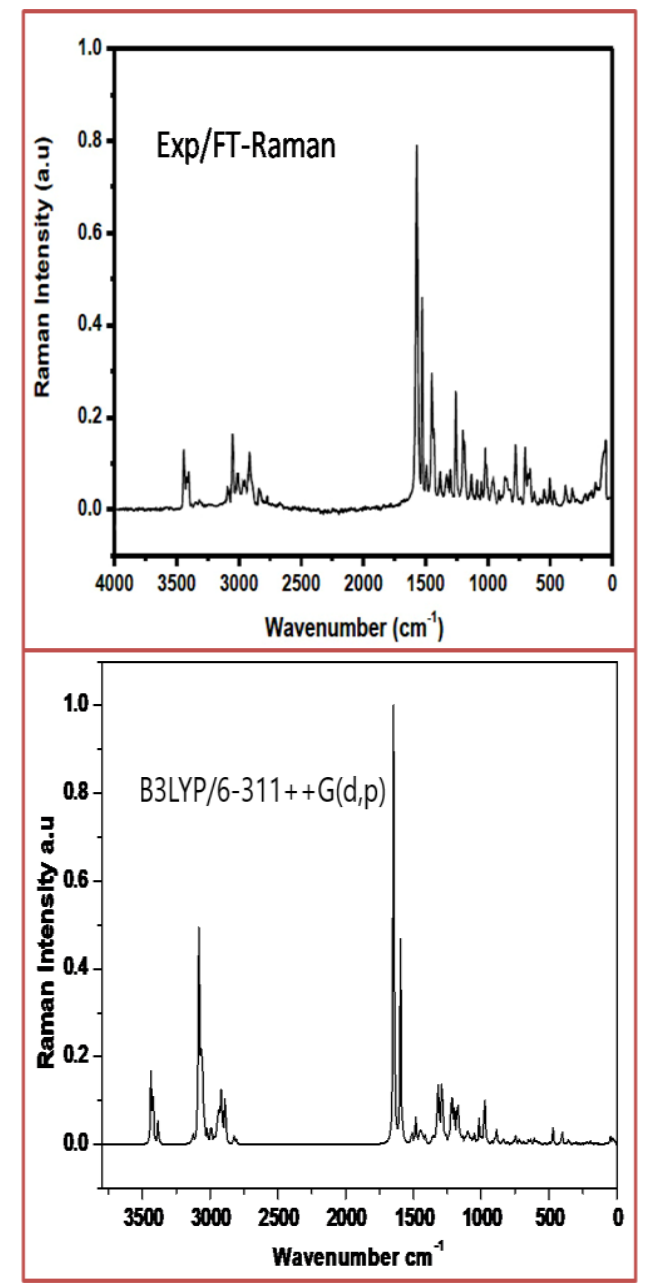

Figure 3. The theoretical and experimental FTRaman spectra of 3-PDPPPHC.

A high-intensity DOS at specific energy levels means that there are many states available for occupation. A DOS of zero intensity means that the system can occupy no states. The variation in the peak height is due to electrons' movement between the $\mathrm{C}=\mathrm{C}$ and $\mathrm{C}-\mathrm{C}$ in the ring of the molecule. The peak at certain energies decreases from the value due to electrons' movement between the $\mathrm{C}=\mathrm{C}$ and $\mathrm{C}-\mathrm{C}$ in the ring of the molecule.

\subsection{Molecular electrostatic potential analysis.}

In this study, a 3D MEP, ESP, and TD plot of 3-PDPPPHC molecule are shown in Fig. 6. In MEP map, the maximum positive/negative regions are preferred sites for nucleophilic/electrophilic attack. They are represented by Blue/Red color, respectively. The 
importance of MEP lies in the fact that it simultaneously displays molecular size, shape, and positive, negative, and neutral electrostatic potential regions in terms of color grading (Fig. 6) and is very useful in research of molecular structure with its physiochemical property relationship [54]. The Potential increases in the order: red < orange < yellow < green $<$ blue. In this study, the electrostatic potential plot is based on the ED distribution within the molecule at different points. The lone pair atoms (sulfur \& nitrogen) and hydrogen atoms in thiosemicarbazone are covered respectively by Red and blue regions. At the same time, the rest of the molecule is neutral. The positive and negative potential of the 3-PDPPPHC molecule ranges from $-6.681 \mathrm{e}^{-2}$ a.u to $6.681 \mathrm{e}^{-2}$ a.u. These two ends of the molecule, which are positively and negatively charged, are prone to the electrophilic and nucleophilic attack of the title molecule.

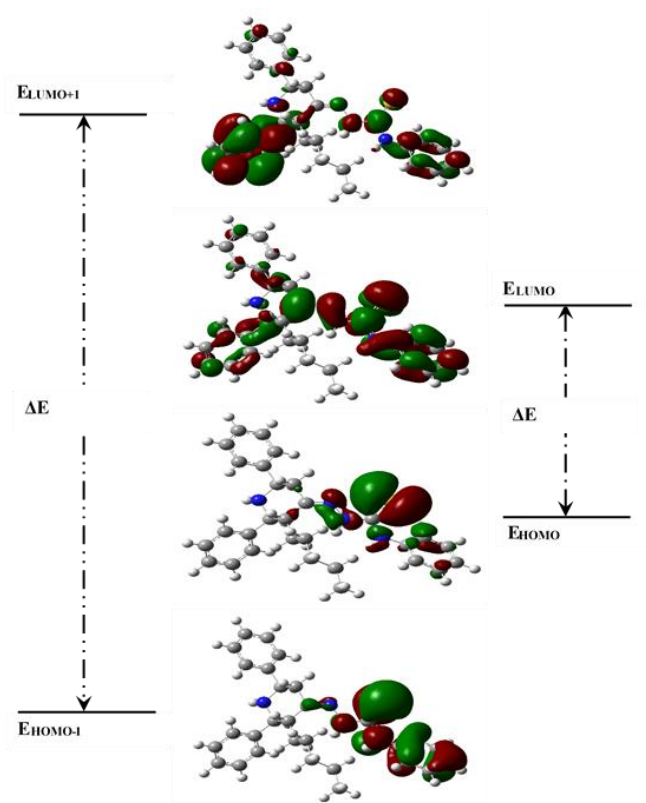

Figure 4. Frontier molecular orbitals of 3-PDPPPHC.



Figure 5. Density of states (DOS) diagrams for 3-PDPPPHC. 
Table 2. The vibrational assignments of 3-PDPPPHC

\begin{tabular}{|c|c|c|c|c|c|c|c|c|c|}
\hline \multirow{3}{*}{ Mode No } & \multirow{2}{*}{\multicolumn{2}{|c|}{$\begin{array}{c}\text { Observed Frequencies } \\
\left(\mathbf{c m}^{-1}\right)\end{array}$}} & \multirow{2}{*}{\multicolumn{2}{|c|}{$\begin{array}{l}\text { Calculated Frequencies } \\
\left(\mathrm{cm}^{-1}\right)\end{array}$}} & \multirow{2}{*}{\multicolumn{2}{|c|}{ IR Intensity }} & \multirow{2}{*}{\multicolumn{2}{|c|}{ Raman Intensity }} & \multirow{3}{*}{$\begin{array}{c}\text { Vibrational Assignments } \\
\text { TED } \geq 10 \%{ }^{\mathrm{d}} \\
\end{array}$} \\
\hline & & & & & & & & & \\
\hline & FT-IR & FT-Raman & Un Scaled & Scaled $^{\mathrm{a}}$ & Abs. & Rel $^{\mathbf{b}}$. & Abs. & Rel $^{\mathrm{c}}$ & \\
\hline 1 & 3433 & 3434 & 3575 & 3435 & 49.82 & 19.71 & 358.58 & 100.00 & $\mathrm{VN}_{28} \mathrm{H}_{29}(92)$ \\
\hline 2 & 3374 & 3375 & 3561 & 3421 & 54.09 & 21.40 & 219.94 & 61.34 & $\mathrm{VN}_{27} \mathrm{H}_{30}(92)$ \\
\hline 3 & 3308 & 3310 & 3521 & 3383 & 0.42 & 0.17 & 107.60 & 30.01 & $\mathrm{VN}_{9} \mathrm{H}_{10}(99)$ \\
\hline 4 & & & 3256 & 3128 & 0.99 & 0.39 & 43.74 & 12.20 & $\mathrm{VC}_{60} \mathrm{H}_{64}(98)$ \\
\hline 5 & 3084 & 3083 & 3210 & 3084 & 13.15 & 5.20 & 327.00 & 91.19 & $\mathrm{VC}_{47} \mathrm{H}_{64}(63)+\mathrm{VC}_{60} \mathrm{H}_{64}(16)$ \\
\hline 6 & & & 3210 & 3084 & 6.69 & 2.65 & 156.45 & 43.63 & $\mathrm{VC}_{37} \mathrm{H}_{40}(47)+\mathrm{VC}_{39} \mathrm{H}_{44}(21)+\mathrm{VC}_{43} \mathrm{H}_{57}(16)$ \\
\hline 7 & & & 3209 & 3083 & 29.74 & 11.77 & 329.42 & 91.87 & $\mathrm{VC}_{61} \mathrm{H}_{66}(24)+\mathrm{VC}_{63} \mathrm{H}_{67}(16)+\mathrm{VC}_{65} \mathrm{H}_{68}(58)$ \\
\hline 8 & & & 3203 & 3077 & 13.65 & 5.40 & 166.32 & 46.38 & $\mathrm{VC}_{37} \mathrm{H}_{40}(25)+\mathrm{VC}_{41} \mathrm{H}_{45}(22)+\mathrm{VC}_{43} \mathrm{H}_{57}(25)+\mathrm{VC}_{53} \mathrm{H}_{56}(10)$ \\
\hline 9 & & & 3203 & 3077 & 45.85 & 18.14 & 99.49 & 27.74 & $\mathrm{VC}_{47} \mathrm{H}_{50}(25)+\mathrm{VC}_{51} \mathrm{H}_{55}(22)+\mathrm{VC}_{53} \mathrm{H}_{56}(10)$ \\
\hline 10 & & & 3194 & 3069 & 24.85 & 9.83 & 105.08 & 29.30 & $\mathrm{VC}_{61} \mathrm{H}_{66}(51)+\mathrm{VC}_{63} \mathrm{H}_{67}(40)$ \\
\hline 11 & & & 3192 & 3067 & 22.11 & 8.75 & 96.55 & 26.93 & $\mathrm{VC}_{38} \mathrm{H}_{42}(10)+\mathrm{VC}_{39} \mathrm{H}_{44}(27)+\mathrm{VC}_{41} \mathrm{H}_{45}(40)+\mathrm{VC}_{43} \mathrm{H}_{57}(14)$ \\
\hline 12 & & & 3191 & 3066 & 21.72 & 8.59 & 105.04 & 29.29 & $\mathrm{VC}_{48} \mathrm{H}_{52}(13)+\mathrm{VC}_{49} \mathrm{H}_{54}(26)+\mathrm{VC}_{51} \mathrm{H}_{55}(36)+\mathrm{VC}_{53} \mathrm{H}_{56}(19)$ \\
\hline 13 & & & 3185 & 3060 & 0.02 & 0.01 & 91.52 & 25.52 & $\mathrm{VC}_{61} \mathrm{H}_{66}(14)+\mathrm{VC}_{63} \mathrm{H}_{67}(42)+\mathrm{VC}_{65} \mathrm{H}_{68}(38)$ \\
\hline 14 & 3058 & 3057 & 3182 & 3057 & 0.16 & 0.06 & 91.16 & 25.42 & $\mathrm{VC}_{38} \mathrm{H}_{42}(12)+\mathrm{VC}_{39} \mathrm{H}_{44}(47)+\mathrm{VC}_{43} \mathrm{H}_{57}(31)$ \\
\hline 15 & & & 3180 & 3055 & 0.62 & 0.25 & 103.08 & 28.75 & $\mathrm{VC}_{48} \mathrm{H}_{52}(20)+\mathrm{VC}_{49} \mathrm{H}_{54}(49)+\mathrm{VC}_{53} \mathrm{H}_{56}(25)$ \\
\hline 16 & & & 3173 & 3049 & 5.87 & 2.32 & 20.79 & 5.80 & $\mathrm{VC}_{48} \mathrm{H}_{52}(62)+\mathrm{VC}_{51} \mathrm{H}_{55}(23)$ \\
\hline 17 & & & 3172 & 3048 & 6.84 & 2.71 & 23.95 & 6.68 & $\mathrm{VC}_{38} \mathrm{H}_{42}(73)+\mathrm{VC}_{41} \mathrm{H}_{45}(19)$ \\
\hline 18 & 3028 & 3030 & 3166 & 3042 & 16.18 & 6.40 & 65.88 & 18.37 & $\mathrm{VC}_{22} \mathrm{H}_{24}(63)+\mathrm{VC}_{22} \mathrm{H}_{25}(33)$ \\
\hline 19 & & & 3144 & 3021 & 6.25 & 2.47 & 44.47 & 12.40 & $\mathrm{VC}_{4} \mathrm{H}_{8}(88)+\mathrm{VC}_{4} \mathrm{H}_{7}(12)$ \\
\hline 20 & & & 3115 & 2993 & 35.20 & 13.93 & 60.81 & 16.96 & $\mathrm{VC}_{59} \mathrm{H}_{62}(88)+\mathrm{VC}_{61} \mathrm{H}_{66}(10)$ \\
\hline 21 & & & 3113 & 2991 & 40.19 & 15.90 & 51.90 & 14.47 & $\mathrm{VC}_{22} \mathrm{H}_{23}(59)+\mathrm{VC}_{22} \mathrm{H}_{25}(28)$ \\
\hline 22 & & & 3087 & 2966 & 55.71 & 22.05 & 31.51 & 8.79 & $\mathrm{VC}_{11} \mathrm{H}_{12}(63)+\mathrm{VC}_{14} \mathrm{H}_{15}(19)+\mathrm{VC}_{14} \mathrm{H}_{33}(11)$ \\
\hline 23 & 2948 & 2949 & 3070 & 2950 & 31.11 & 12.31 & 40.89 & 11.40 & $\mathrm{VC}_{11} \mathrm{H}_{12}(14)+\mathrm{VC}_{14} \mathrm{H}_{15}(13)+\mathrm{VC}_{16} \mathrm{H}_{17}(36)+\mathrm{VC}_{16} \mathrm{H}_{18}(24)$ \\
\hline 24 & & & 3065 & 2945 & 23.56 & 9.32 & 72.15 & 20.12 & $\mathrm{VC}_{11} \mathrm{H}_{12}(18)+\mathrm{VC}_{14} \mathrm{H}_{15}(22)+\mathrm{VC}_{14} \mathrm{H}_{33}(35)+\mathrm{VC}_{16} \mathrm{H}_{17}(19)$ \\
\hline 25 & 2925 & 2930 & 3054 & 2934 & 36.20 & 14.33 & 95.62 & 26.67 & $\mathrm{VC}_{4} \mathrm{H}_{8}(12)+\mathrm{VC}_{4} \mathrm{H}_{7}(86)$ \\
\hline 26 & & & 3042 & 2923 & 33.58 & 13.29 & 132.97 & 37.08 & $\mathrm{VC}_{22} \mathrm{H}_{23}(34)+\mathrm{VC}_{22} \mathrm{H}_{24}(29)+\mathrm{VC}_{22} \mathrm{H}_{25}(35)$ \\
\hline 27 & & & 3036 & 2917 & 4.59 & 1.82 & 98.45 & 27.46 & $\mathrm{VC}_{19} \mathrm{H}_{20}(51)+\mathrm{VC}_{19} \mathrm{H}_{21}(20)$ \\
\hline 28 & & & 3035 & 2916 & 31.01 & 12.27 & 46.07 & 12.85 & $\mathrm{VC}_{2} \mathrm{H}_{6}(10)+\mathrm{VC}_{14} \mathrm{H}_{15}(34)+\mathrm{VC}_{14} \mathrm{H}_{33}(32)$ \\
\hline 29 & & & 3026 & 2907 & 11.10 & 4.39 & 28.99 & 8.08 & $\mathrm{VC}_{2} \mathrm{H}_{6}(61)+\mathrm{VC}_{16} \mathrm{H}_{18}(11)$ \\
\hline 30 & & & 3024 & 2905 & 48.80 & 19.31 & 26.78 & 7.47 & $\mathrm{VC}_{16} \mathrm{H}_{17}(29)+\mathrm{VC}_{16} \mathrm{H}_{18}(53)$ \\
\hline 31 & & & 3010 & 2892 & 22.39 & 8.86 & 142.31 & 39.69 & $\mathrm{VC}_{2} \mathrm{H}_{6}(17)+\mathrm{VC}_{11} \mathrm{H}_{13}(66)+\mathrm{VC}_{19} \mathrm{H}_{21}(14)$ \\
\hline 32 & 2855 & 2860 & 3000 & 2882 & 37.04 & 14.66 & 71.82 & 20.03 & $\mathrm{VC}_{11} \mathrm{H}_{13}(10)+\mathrm{VC}_{19} \mathrm{H}_{20}(30)+\mathrm{VC}_{19} \mathrm{H}_{21}(55)$ \\
\hline 33 & & & 2940 & 2825 & 36.57 & 14.47 & 38.49 & 10.74 & $\mathrm{VC}_{5} \mathrm{H}_{34}(98)$ \\
\hline 34 & & & 2923 & 2808 & 33.45 & 13.24 & 26.61 & 7.42 & $\mathrm{VC}_{1} \mathrm{H}_{35}(98)$ \\
\hline 35 & 1594 & 1595 & 1713 & 1646 & 2.57 & 1.02 & 1282.17 & 357.57 & $\mathrm{VN}_{26} \mathrm{C}_{3}(78)$ \\
\hline 36 & & & 1662 & 1597 & 4.86 & 1.92 & 108.43 & 30.24 & $\mathrm{VC}_{48} \mathrm{C}_{51}(31)+\mathrm{VC}_{53} \mathrm{C}_{49}(14)+\beta \mathrm{C}_{51} \mathrm{C}_{53} \mathrm{C}_{49}(14)$ \\
\hline 37 & & & 1660 & 1595 & 5.35 & 2.12 & 91.31 & 25.47 & $\beta_{3} \mathrm{C}_{36} \mathrm{C}_{37} \mathrm{C}_{39}(13)+\mathrm{VC}_{38} \mathrm{C}_{41}(37)+\mathrm{VC}_{43} \mathrm{C}_{39}(10)$ \\
\hline 38 & & & 1660 & 1595 & 50.28 & 19.90 & 343.94 & 95.92 & $\mathrm{VC}_{60} \mathrm{C}_{63}(19)+\mathrm{VC}_{59} \mathrm{C}_{61}(16)+\mathrm{VC}_{65} \mathrm{C}_{61}(12)+\beta \mathrm{C}_{59} \mathrm{C}_{58} \mathrm{C}_{60}(12)$ \\
\hline
\end{tabular}


https://doi.org/10.33263/BRIAC114.1183311855

\begin{tabular}{|c|c|c|c|c|c|c|c|c|c|}
\hline 39 & & & 1651 & 1586 & 29.82 & 11.80 & 3.88 & 1.08 & $V^{2} C_{63} C_{65}(22)+V_{65} C_{61}(18)+\beta C_{58} C_{60} C_{60}(19)+\beta C_{60} C_{63} C_{65}(11)$ \\
\hline 40 & & & 1641 & 1577 & 1.91 & 0.76 & 12.47 & 3.48 & $\mathrm{VC}_{51} \mathrm{C}_{53}(25)+\mathrm{VC}_{46} \mathrm{C}_{48}(16)$ \\
\hline 41 & 1535 & 1537 & 1640 & 1576 & 0.36 & 0.14 & 5.36 & 1.49 & $\mathrm{VN}_{29} \mathrm{C}_{50}(38)+\mathrm{VC}_{43} \mathrm{C}_{39}(19)+\mathrm{VC}_{36} \mathrm{C}_{37}(18)$ \\
\hline 42 & 1493 & 1492 & 1574 & 1512 & 247.38 & 97.89 & 48.78 & 13.60 & $\beta \mathrm{H}_{29} \mathrm{~N}_{28} \mathrm{C}_{32}(54)$ \\
\hline 43 & & & 1553 & 1492 & 179.92 & 71.20 & 9.55 & 2.66 & $\beta \mathrm{H}_{30} \mathrm{~N}_{27} \mathrm{~N}_{26}(40)+\beta \mathrm{H}_{12} \mathrm{C}_{11} \mathrm{H}_{13}(54)$ \\
\hline 44 & & & 1541 & 1481 & 99.23 & 39.27 & 76.29 & 21.28 & $\beta \mathrm{H}_{64} \mathrm{C}_{60} \mathrm{C}_{63}(12)+\beta \mathrm{H}_{62} \mathrm{C}_{59} \mathrm{C}_{61}(20)+\beta \mathrm{H}_{66} \mathrm{C}_{61} \mathrm{C}_{59}(14)+\beta \mathrm{H}_{67} \mathrm{C}_{63} \mathrm{C}_{60}(19)$ \\
\hline 45 & & & 1538 & 1478 & 17.09 & 6.76 & 3.54 & 0.99 & $\beta \mathrm{H}_{50} \mathrm{C}_{47} \mathrm{C}_{46}(13)+\beta \mathrm{H}_{52} \mathrm{C}_{48} \mathrm{C}_{51}(16)+\beta \mathrm{H}_{54} \mathrm{C}_{49} \mathrm{C}_{53}(18)+\beta \mathrm{H}_{55} \mathrm{C}_{51} \mathrm{C}_{53}(17)$ \\
\hline 46 & & & 1536 & 1476 & 14.02 & 5.55 & 0.91 & 0.25 & $\beta \mathrm{H}_{40} \mathrm{C}_{37} \mathrm{C}_{39}(15)+\beta \mathrm{H}_{42} \mathrm{C}_{38} \mathrm{C}_{41}(16)+\beta \mathrm{H}_{44} \mathrm{C}_{39} \mathrm{C}_{43}(18)+\beta \mathrm{H}_{45} \mathrm{C}_{41} \mathrm{C}_{38}(17)$ \\
\hline 47 & & & 1526 & 1466 & 15.38 & 6.09 & 0.82 & 0.23 & $\beta \mathrm{H}_{23} \mathrm{C}_{22} \mathrm{H}_{25}(19)+\beta \mathrm{H}_{20} \mathrm{C}_{19} \mathrm{H}_{21}(50)$ \\
\hline 48 & & & 1516 & 1457 & 123.33 & 48.80 & 6.93 & 1.93 & $\beta \mathrm{H}_{30} \mathrm{~N}_{27} \mathrm{~N}_{26}(25)+\beta \mathrm{H}_{12} \mathrm{C}_{11} \mathrm{H}_{13}(28)+\beta \mathrm{H}_{15} \mathrm{C}_{14} \mathrm{H}_{33}(25)$ \\
\hline 49 & & & 1513 & 1454 & 6.76 & 2.67 & 15.30 & 4.27 & $\beta \mathrm{H}_{23} \mathrm{C}_{22} \mathrm{C}_{19}(25)+\Gamma \mathrm{C}_{22} \mathrm{H}_{23} \mathrm{C}_{19} \mathrm{H}_{24}(65)$ \\
\hline 50 & & & 1511 & 1452 & 0.93 & 0.37 & 25.91 & 7.22 & $\beta \mathrm{H}_{23} \mathrm{C}_{22} \mathrm{C}_{22}(35)+\beta \mathrm{H}_{15} \mathrm{C}_{14} \mathrm{H}_{33}(13)+\Gamma \mathrm{C}_{22} \mathrm{H}_{23} \mathrm{C}_{19} \mathrm{H}_{25}(10)$ \\
\hline 51 & 1444 & 1445 & 1505 & 1446 & 68.31 & 27.03 & 5.32 & 1.48 & $\mathrm{VC}_{51} \mathrm{C}_{53}(25)+\beta \mathrm{H}_{12} \mathrm{C}_{11} \mathrm{H}_{13}(13)+\beta \mathrm{H}_{15} \mathrm{C}_{14} \mathrm{H}_{33}(47)$ \\
\hline 52 & & & 1501 & 1442 & 1.83 & 0.72 & 24.76 & 6.90 & $\beta \mathrm{H}_{17} \mathrm{C}_{16} \mathrm{H}_{18}(73)+\beta \mathrm{H}_{20} \mathrm{C}_{19} \mathrm{H}_{21}(20)$ \\
\hline 53 & & & 1497 & 1438 & 9.37 & 3.71 & 1.97 & 0.55 & $\beta \mathrm{H}_{54} \mathrm{C}_{49} \mathrm{C}_{53}(11)+\beta \mathrm{H}_{55} \mathrm{C}_{51} \mathrm{C}_{53}(12)+\beta \mathrm{H}_{56} \mathrm{C}_{53} \mathrm{C}_{51}(26)$ \\
\hline 54 & & & 1496 & 1437 & 8.38 & 3.32 & 2.05 & 0.57 & $\beta \mathrm{H}_{36} \mathrm{C}_{37} \mathrm{C}_{39}(11)+\beta \mathrm{H}_{44} \mathrm{C}_{39} \mathrm{C}_{43}(10)+\beta \mathrm{H}_{45} \mathrm{C}_{41} \mathrm{C}_{38}(10)+\beta \mathrm{H}_{57} \mathrm{C}_{43} \mathrm{C}_{41}(25)$ \\
\hline 55 & & & 1488 & 1430 & 41.12 & 16.27 & 9.74 & 2.71 & $\beta \mathrm{H}_{29} \mathrm{~N}_{28} \mathrm{C}_{32}(10)+\beta \mathrm{H}_{7} \mathrm{C}_{4} \mathrm{H}_{8}(26)+\beta \mathrm{H}_{66} \mathrm{C}_{61} \mathrm{C}_{59}(11)+\beta \mathrm{H}_{68} \mathrm{C}_{65} \mathrm{C}_{63}(16)$ \\
\hline 56 & & & 1484 & 1426 & 63.00 & 24.93 & 13.25 & 3.70 & $\mathrm{BH}_{7} \mathrm{C}_{4} \mathrm{H}_{8}(55)$ \\
\hline 57 & & & 1469 & 1411 & 42.75 & 16.92 & 26.17 & 7.30 & $\beta \mathrm{H}_{10} \mathrm{~N}_{9} \mathrm{C}_{5}(73)$ \\
\hline 58 & & & 1429 & 1373 & 1.50 & 0.59 & 4.14 & 1.16 & $\beta \mathrm{H}_{24} \mathrm{C}_{22} \mathrm{C}_{19}(36)+\beta \mathrm{H}_{23} \mathrm{C}_{22} \mathrm{H}_{25}(29)+\Gamma \mathrm{C}_{22} \mathrm{H}_{23} \mathrm{C}_{19} \mathrm{H}_{25}(31)$ \\
\hline 59 & 1382 & 1385 & 1414 & 1359 & 2.73 & 1.08 & 17.39 & 4.85 & $\beta \mathrm{H}_{6} \mathrm{C}_{2} \mathrm{H}_{11}(23)+\beta \mathrm{H}_{34} \mathrm{C}_{5} \mathrm{~N}_{9}(21)$ \\
\hline 60 & & & 1409 & 1354 & 2.63 & 1.04 & 8.70 & 2.43 & $\beta \mathrm{H}_{34} \mathrm{C}_{5} \mathrm{~N}_{9}(13)+\beta \mathrm{H}_{15} \mathrm{C}_{14} \mathrm{C}_{11}(20)$ \\
\hline 61 & & & 1404 & 1349 & 1.06 & 0.42 & 2.21 & 0.62 & $\beta \mathrm{H}_{20} \mathrm{C}_{19} \mathrm{C}_{22}(13)+\beta \mathrm{C}_{16} \mathrm{H}_{17} \mathrm{C}_{14} \mathrm{H}_{18}(36)$ \\
\hline 62 & & & 1401 & 1346 & 1.62 & 0.64 & 6.67 & 1.86 & $\beta \mathrm{H}_{20} \mathrm{C}_{19} \mathrm{C}_{22}(21)+\beta \mathrm{H}_{20} \mathrm{C}_{19} \mathrm{C}_{22}(12)+\Gamma \mathrm{C}_{16} \mathrm{H}_{17} \mathrm{C}_{14} \mathrm{H}_{18}(14)$ \\
\hline 63 & 1325 & 1328 & 1384 & 1330 & 11.24 & 4.45 & 42.85 & 11.95 & $\mathrm{\beta H}_{35} \mathrm{C}_{1} \mathrm{C}_{36}(42)$ \\
\hline 64 & & & 1378 & 1324 & 124.68 & 49.34 & 15.66 & 4.37 & $\mathrm{VN}_{28} \mathrm{C}_{32}(14)+\beta \mathrm{H}_{64} \mathrm{C}_{60} \mathrm{C}_{63}(10)+\beta \mathrm{H}_{62} \mathrm{C}_{59} \mathrm{C}_{61}(12)$ \\
\hline 65 & 1300 & 1299 & 1374 & 1320 & 12.83 & 5.08 & 140.20 & 39.10 & $\Gamma \mathrm{C}_{1} \mathrm{C}_{2} \mathrm{C}_{36} \mathrm{H}_{35}(23)+\Gamma \mathrm{C}_{5} \mathrm{C}_{46} \mathrm{~N}_{9} \mathrm{H}_{34}(33)$ \\
\hline 66 & & & 1363 & 1310 & 80.22 & 31.74 & 44.71 & 12.47 & $\mathrm{VC}_{60} \mathrm{C}_{63}(24)+\mathrm{VC}_{59} \mathrm{C}_{61}(32)$ \\
\hline 67 & & & 1361 & 1308 & 1.97 & 0.78 & 3.16 & 0.88 & $\mathrm{VC}_{53} \mathrm{C}_{49}(27)+\mathrm{VC}_{46} \mathrm{C}_{48}(15)+\beta \mathrm{H}_{50} \mathrm{C}_{47} \mathrm{C}_{46}(18)+\beta_{52} \mathrm{C}_{48} \mathrm{C}_{51}(19)$ \\
\hline 68 & & & 1360 & 1307 & 0.20 & 0.08 & 1.66 & 0.46 & $\mathrm{VC}_{41} \mathrm{C}_{43}(26)+\mathrm{VC}_{36} \mathrm{C}_{37}(17)+\beta \mathrm{H}_{40} \mathrm{C}_{37} \mathrm{C}_{39}(17)+\beta_{42} \mathrm{C}_{38} \mathrm{C}_{41}(19)$ \\
\hline 69 & & & 1352 & 1299 & 1.59 & 0.63 & 8.19 & 2.28 & $\beta \mathrm{H}_{12} \mathrm{C}_{11} \mathrm{C}_{14}(18)+\beta \mathrm{H}_{17} \mathrm{C}_{16} \mathrm{C}_{14}(20)+\beta \mathrm{H}_{20} \mathrm{C}_{19} \mathrm{C}_{22}(11)$ \\
\hline 70 & & & 1346 & 1293 & 95.14 & 37.65 & 119.17 & 33.23 & $\mathrm{VN}_{28} \mathrm{C}_{32}(15)+\mathrm{VN}_{28} \mathrm{C}_{58}(12)+\beta \mathrm{H}_{64} \mathrm{C}_{60} \mathrm{C}_{63}(14)$ \\
\hline 71 & & & 1345 & 1292 & 82.09 & 32.48 & 14.42 & 4.02 & $\beta \mathrm{H}_{12} \mathrm{C}_{11} \mathrm{C}_{14}(11)+\tau \mathrm{H}_{33} \mathrm{C}_{14} \mathrm{C}_{16} \mathrm{C}_{19}(15)$ \\
\hline 72 & & & 1336 & 1284 & 18.61 & 7.36 & 68.44 & 19.09 & $\mathrm{VC}_{46} \mathrm{C}_{48}(10)$ \\
\hline 73 & & & 1333 & 1281 & 21.83 & 8.64 & 21.83 & 6.09 & $\beta \mathrm{H}_{17} \mathrm{C}_{16} \mathrm{C}_{14}(13)+\Gamma \mathrm{C}_{1} \mathrm{C}_{2} \mathrm{C}_{36} \mathrm{H}_{35}(13)+\tau \mathrm{H}_{18} \mathrm{C}_{16} \mathrm{C}_{19} \mathrm{H}_{21}(10)$ \\
\hline 74 & 1269 & 1268 & 1322 & 1270 & 18.52 & 7.33 & 18.80 & 5.24 & $\beta \mathrm{H}_{12} \mathrm{C}_{11} \mathrm{C}_{14}(10)+\tau \mathrm{H}_{18} \mathrm{C}_{16} \mathrm{C}_{19} \mathrm{H}_{21}(17)$ \\
\hline 75 & & & 1311 & 1260 & 48.91 & 19.35 & 10.10 & 2.82 & $\beta \mathrm{H}_{17} \mathrm{C}_{16} \mathrm{C}_{14}(15)$ \\
\hline 76 & & & 1310 & 1259 & 14.42 & 5.71 & 6.57 & 1.83 & $\beta \mathrm{H}_{15} \mathrm{C}_{14} \mathrm{C}_{11}(10)+\beta \mathrm{H}_{20} \mathrm{C}_{19} \mathrm{C}_{22}(17)$ \\
\hline 77 & & & 1291 & 1240 & 2.22 & 0.88 & 8.72 & 2.43 & $\beta \mathrm{H}_{34} \mathrm{C}_{5} \mathrm{~N}_{9}(10)+\tau \mathrm{H}_{8} \mathrm{C}_{4} \mathrm{C}_{3} \mathrm{~N}_{26}(22)+\tau \mathrm{H}_{7} \mathrm{C}_{4} \mathrm{C}_{3} \mathrm{H}_{2}(12)$ \\
\hline 78 & & & 1279 & 1229 & 5.90 & 2.34 & 11.08 & 3.09 & $\tau \mathrm{H}_{18} \mathrm{C}_{16} \mathrm{C}_{19} \mathrm{H}_{21}(11)$ \\
\hline 79 & & & 1268 & 1218 & 48.49 & 19.19 & 207.65 & 57.91 & $\mathrm{VC}_{60} \mathrm{C}_{63}(11)+\beta \mathrm{C}_{58} \mathrm{C}_{60} \mathrm{C}_{63}(12)+\mathrm{VN}_{28} \mathrm{C}_{58}(13)$ \\
\hline 80 & & & 1253 & 1204 & 49.30 & 19.51 & 35.93 & 10.02 & $\tau \mathrm{H}_{6} \mathrm{C}_{2} \mathrm{C}_{3} \mathrm{C}_{4}(27)$ \\
\hline 81 & & & 1245 & 1196 & 66.86 & 26.46 & 70.73 & 19.72 & $\beta \mathrm{H}_{7} \mathrm{C}_{4} \mathrm{C}_{3}(11)$ \\
\hline
\end{tabular}

https://biointerfaceresearch.com/ 
https://doi.org/10.33263/BRIAC114.1183311855

\begin{tabular}{|c|c|c|c|c|c|c|c|c|c|}
\hline 82 & 1180 & 1180 & 1229 & 1181 & 221.27 & 87.56 & 18.18 & 5.07 & $\mathrm{VN}_{27} \mathrm{C}_{32}(16)$ \\
\hline 83 & & & 1223 & 1175 & 252.70 & 100.00 & 86.21 & 24.04 & $\mathrm{VC}_{46} \mathrm{C}_{5}(18)$ \\
\hline 84 & & & 1221 & 1173 & 126.58 & 50.09 & 54.18 & 15.11 & $\mathrm{VC}_{36} \mathrm{C}_{1}(21)$ \\
\hline 85 & & & 1209 & 1162 & 2.63 & 1.04 & 14.14 & 3.94 & $\beta \mathrm{H}_{64} \mathrm{C}_{60} \mathrm{C}_{63}(20)+\beta \mathrm{H}_{62} \mathrm{C}_{59} \mathrm{C}_{61}(21)+\beta \mathrm{H}_{66} \mathrm{C}_{61} \mathrm{C}_{59}(15)+\beta \mathrm{H}_{67} \mathrm{C}_{63} \mathrm{C}_{60}(18)$ \\
\hline 86 & & & 1207 & 1160 & 5.61 & 2.22 & 10.96 & 3.06 & $\tau \mathrm{C}_{14} \mathrm{C}_{11} \mathrm{C}_{16} \mathrm{H}_{15}(13)$ \\
\hline 87 & & & 1204 & 1157 & 7.78 & 3.08 & 5.69 & 1.59 & $\beta \mathrm{H}_{42} \mathrm{C}_{38} \mathrm{C}_{41}(11)+\beta \mathrm{H}_{52} \mathrm{C}_{48} \mathrm{C}_{51}(11)$ \\
\hline 88 & 1152 & 1153 & 1202 & 1155 & 3.27 & 1.29 & 4.76 & 1.33 & $\beta \mathrm{H}_{42} \mathrm{C}_{38} \mathrm{C}_{41}(12)+\beta \mathrm{H}_{52} \mathrm{C}_{48} \mathrm{C}_{51}(12)+\beta \mathrm{H}_{55} \mathrm{C}_{51} \mathrm{C}_{53}(10)$ \\
\hline 89 & & & 1187 & 1140 & 0.83 & 0.33 & 8.95 & 2.50 & $\beta \mathrm{H}_{66} \mathrm{C}_{61} \mathrm{C}_{59}(22)+\beta \mathrm{H}_{67} \mathrm{C}_{63} \mathrm{C}_{60}(18)+\beta \mathrm{H}_{68} \mathrm{C}_{65} \mathrm{C}_{63}(35)$ \\
\hline 90 & & & 1187 & 1140 & 0.04 & 0.02 & 6.93 & 1.93 & $\beta \mathrm{H}_{44} \mathrm{C}_{39} \mathrm{C}_{43}(19)+\beta \mathrm{H}_{45} \mathrm{C}_{41} \mathrm{C}_{38}(15)+\beta \mathrm{H}_{57} \mathrm{C}_{43} \mathrm{C}_{41}(33)$ \\
\hline 91 & & & 1187 & 1140 & 1.89 & 0.75 & 5.61 & 1.57 & $\mathrm{VC}_{53} \mathrm{C}_{49}(10)+\beta \mathrm{H}_{54} \mathrm{C}_{49} \mathrm{C}_{53}(19)+\beta \mathrm{H}_{55} \mathrm{C}_{51} \mathrm{C}_{53}(14)+\beta \mathrm{H}_{56} \mathrm{C}_{53} \mathrm{C}_{51}(32)$ \\
\hline 92 & & & 1181 & 1135 & 20.27 & 8.02 & 6.19 & 1.73 & $\beta \mathrm{H}_{7} \mathrm{C}_{4} \mathrm{C}_{3}(13)$ \\
\hline 93 & 1109 & 1112 & 1160 & 1115 & 1.62 & 0.64 & 27.05 & 7.54 & $\mathrm{VN}_{27} \mathrm{~N}_{26}(25)$ \\
\hline 94 & & & 1145 & 1100 & 14.56 & 5.76 & 31.48 & 8.78 & $\mathrm{VN}_{27} \mathrm{~N}_{26}(13)$ \\
\hline 95 & & & 1134 & 1090 & 22.19 & 8.78 & 27.38 & 7.64 & $\mathrm{VN}_{9} \mathrm{C}_{5}(41)+\mathrm{VC}_{4} \mathrm{C}_{5}(10)$ \\
\hline 96 & & & 1119 & 1075 & 19.58 & 7.75 & 9.09 & 2.53 & $\mathrm{VN}_{27} \mathrm{~N}_{26}(11)+\Gamma \mathrm{C}_{11} \mathrm{C}_{2} \mathrm{C}_{14} \mathrm{H}_{12}(10)$ \\
\hline 97 & & & 1115 & 1071 & 8.97 & 3.55 & 1.73 & 0.48 & $\beta_{68} \mathrm{H}_{65} \mathrm{C}_{63}(11)$ \\
\hline 98 & 1068 & 1067 & 1114 & 1070 & 0.52 & 0.21 & 1.77 & 0.49 & $\beta \mathrm{H}_{55} \mathrm{C}_{51} \mathrm{C}_{53}(45)$ \\
\hline 99 & & & 1105 & 1062 & 3.82 & 1.51 & 6.89 & 1.92 & $\beta \mathrm{H}_{56} \mathrm{C}_{53} \mathrm{C}_{51}(30)$ \\
\hline 100 & & & 1095 & 1052 & 3.89 & 1.54 & 7.26 & 2.02 & $\mathrm{VC}_{11} \mathrm{C}_{2}(14)$ \\
\hline 101 & & & 1094 & 1051 & 62.39 & 24.69 & 16.96 & 4.73 & $\mathrm{VC}_{4} \mathrm{C}_{3}(13)+\mathrm{VN}_{9} \mathrm{C}_{1}(20)+\mathrm{VC}_{11} \mathrm{C}_{2}(11)$ \\
\hline 102 & 1025 & 1030 & 1078 & 1036 & 0.80 & 0.32 & 7.14 & 1.99 & $\mathrm{VC}_{14} \mathrm{C}_{11}(10)+\mathrm{VC}_{16} \mathrm{C}_{14}(33)+\mathrm{VC}_{19} \mathrm{C}_{16}(25)$ \\
\hline 103 & & & 1057 & 1016 & 8.30 & 3.29 & 16.61 & 4.63 & $\mathrm{VC}_{63} \mathrm{C}_{65}(25)+\mathrm{VC}_{65} \mathrm{C}_{61}(23)$ \\
\hline 104 & & & 1056 & 1015 & 2.86 & 1.13 & 35.69 & 9.95 & $\mathrm{VC}_{41} \mathrm{C}_{43}(10)+\mathrm{VC}_{51} \mathrm{C}_{53}(10)$ \\
\hline 105 & & & 1055 & 1014 & 8.53 & 3.37 & 8.07 & 2.25 & $\mathrm{VC}_{41} \mathrm{C}_{43}(17)+\mathrm{VC}_{43} \mathrm{C}_{39}(12)$ \\
\hline 106 & & & 1039 & 998 & 1.21 & 0.48 & 8.32 & 2.32 & $\mathrm{VC}_{22} \mathrm{C}_{19}(43)+\mathrm{VC}_{14} \mathrm{C}_{11}(13)$ \\
\hline 107 & & & 1018 & 978 & 1.09 & 0.43 & 5.18 & 1.44 & $\mathrm{VC}_{22} \mathrm{C}_{19}(11)$ \\
\hline 108 & & & 1017 & 977 & 1.81 & 0.72 & 60.53 & 16.88 & $\beta \mathrm{C}_{38} \mathrm{C}_{41} \mathrm{C}_{43}(11)$ \\
\hline 109 & & & 1016 & 976 & 1.04 & 0.41 & 14.78 & 4.12 & $\beta \mathrm{C}_{41} \mathrm{C}_{43} \mathrm{C}_{39}(11)+\beta \mathrm{C}_{38} \mathrm{C}_{41} \mathrm{C}_{43}(16)$ \\
\hline 110 & & & 1014 & 974 & 0.20 & 0.08 & 73.54 & 20.51 & $\beta \mathrm{C}_{60} \mathrm{C}_{63} \mathrm{C}_{65}(17)+\beta \mathrm{C}_{63} \mathrm{C}_{65} \mathrm{C}_{61}(20)+\beta \mathrm{C}_{65} \mathrm{C}_{61} \mathrm{C}_{59}(35)$ \\
\hline 111 & & & 1010 & 970 & 5.18 & 2.05 & 8.94 & 2.49 & $\beta \mathrm{C}_{63} \mathrm{C}_{65} \mathrm{C}_{61}(22)$ \\
\hline 112 & & & 1003 & 964 & 0.32 & 0.13 & 1.50 & 0.42 & $\tau \mathrm{H}_{40} \mathrm{C}_{37} \mathrm{C}_{39} \mathrm{H}_{44}(22)+\tau \mathrm{H}_{42} \mathrm{C}_{38} \mathrm{C}_{41} \mathrm{H}_{45}(12)+\Gamma \mathrm{C}_{43} \mathrm{C}_{39} \mathrm{C}_{41} \mathrm{H}_{57}(14)$ \\
\hline 113 & & & 1002 & 963 & 0.26 & 0.10 & 0.46 & 0.13 & $\tau \mathrm{H}_{40} \mathrm{C}_{37} \mathrm{C}_{39} \mathrm{H}_{44}(16)+\Gamma \mathrm{C}_{43} \mathrm{C}_{39} \mathrm{C}_{41} \mathrm{H}_{57}(12)+\tau \mathrm{H}_{50} \mathrm{C}_{47} \mathrm{C}_{49} \mathrm{H}_{54}(23)$ \\
\hline 114 & & & 997 & 958 & 2.69 & 1.07 & 4.61 & 1.28 & $\Gamma \mathrm{C}_{53} \mathrm{C}_{49} \mathrm{C}_{51} \mathrm{H}_{56}(10)$ \\
\hline 115 & & & 990 & 951 & 0.59 & 0.23 & 1.92 & 0.54 & $\Gamma \mathrm{C}_{60} \mathrm{C}_{58} \mathrm{C}_{63} \mathrm{H}_{64}(10)+\tau \mathrm{H}_{62} \mathrm{C}_{59} \mathrm{C}_{61} \mathrm{H}_{66}(13)+\mathrm{H}_{64} \mathrm{C}_{60} \mathrm{C}_{63} \mathrm{H}_{67}(51)$ \\
\hline 116 & 941 & 940 & 980 & 942 & 0.18 & 0.07 & 0.38 & 0.11 & $\Gamma \mathrm{H}_{42} \mathrm{C}_{38} \mathrm{C}_{41} \mathrm{H}_{45}(11)+\tau \mathrm{H}_{50} \mathrm{C}_{47} \mathrm{C}_{49} \mathrm{H}_{54}(26)+\tau \mathrm{H}_{52} \mathrm{C}_{48} \mathrm{C}_{51} \mathrm{H}_{55}(40)$ \\
\hline 117 & & & 978 & 940 & 0.55 & 0.22 & 0.22 & 0.06 & $\tau \mathrm{H}_{40} \mathrm{C}_{37} \mathrm{C}_{39} \mathrm{H}_{44}(30)+\tau \mathrm{H}_{42} \mathrm{C}_{38} \mathrm{C}_{41} \mathrm{H}_{45}(40)+\tau \mathrm{H}_{52} \mathrm{C}_{48} \mathrm{C}_{51} \mathrm{H}_{55}(10)$ \\
\hline 118 & & & 961 & 923 & 0.31 & 0.12 & 1.12 & 0.31 & $\tau \mathrm{H}_{62} \mathrm{C}_{59} \mathrm{C}_{61} \mathrm{H}_{66}(56)+\tau \mathrm{H}_{64} \mathrm{C}_{60} \mathrm{C}_{63} \mathrm{H}_{67}(29)$ \\
\hline 119 & 913 & & 959 & 921 & 0.17 & 0.07 & 6.47 & 1.80 & $\mathrm{VC}_{14} \mathrm{C}_{11}(16)+\mathrm{VC}_{2} \mathrm{C}_{1}(15)$ \\
\hline 120 & & & 937 & 900 & 4.91 & 1.94 & 6.45 & 1.80 & $\tau \mathrm{H}_{50} \mathrm{C}_{47} \mathrm{C}_{49} \mathrm{C}_{53}(18)+\Gamma \mathrm{C}_{48} \mathrm{C}_{46} \mathrm{C}_{51} \mathrm{H}_{52}(16)+\Gamma \mathrm{C}_{53} \mathrm{C}_{49} \mathrm{C}_{51} \mathrm{H}_{56}(23)$ \\
\hline 121 & 898 & & 936 & 899 & 3.03 & 1.20 & 10.25 & 2.86 & $\Gamma \mathrm{C}_{37} \mathrm{C}_{36} \mathrm{C}_{39} \mathrm{H}_{40}(16)+\Gamma \mathrm{C}_{38} \mathrm{C}_{36} \mathrm{C}_{41} \mathrm{H}_{42}(16)+\Gamma \mathrm{C}_{43} \mathrm{C}_{39} \mathrm{C}_{41} \mathrm{H}_{57}(21)$ \\
\hline 122 & & & 924 & 888 & 1.03 & 0.41 & 37.35 & 10.42 & $\mathrm{VC}_{4} \mathrm{C}_{5}(28)$ \\
\hline 123 & & & 915 & 879 & 2.06 & 0.81 & 4.11 & 1.15 & $\mathrm{VC}_{2} \mathrm{C}_{1}(18)$ \\
\hline 124 & & & 906 & 870 & 3.45 & 1.37 & 1.88 & 0.52 & $\Gamma \mathrm{C}_{60} \mathrm{C}_{58} \mathrm{C}_{63} \mathrm{H}_{64}(29)+\tau \mathrm{H}_{62} \mathrm{C}_{59} \mathrm{C}_{61} \mathrm{C}_{65}(14)+\tau \mathrm{H}_{62} \mathrm{C}_{59} \mathrm{C}_{61} \mathrm{H}_{66}(10)$ \\
\hline
\end{tabular}

https://biointerfaceresearch.com/ 
https://doi.org/10.33263/BRIAC114.1183311855

\begin{tabular}{|c|c|c|c|c|c|c|c|c|c|}
\hline 125 & & & 890 & 855 & 2.00 & 0.79 & 2.62 & 0.73 & $\mathrm{VC}_{19} \mathrm{C}_{16}(10)+\Gamma \mathrm{C}_{16} \mathrm{C}_{14} \mathrm{C}_{19} \mathrm{H}_{17}(14)$ \\
\hline 126 & & & 879 & 845 & 35.75 & 14.15 & 7.33 & 2.05 & $\mathrm{VN}_{28} \mathrm{C}_{58}(10)+\beta \mathrm{C}_{63} \mathrm{C}_{65} \mathrm{C}_{61}(16)$ \\
\hline 127 & & & 868 & 834 & 0.91 & 0.36 & 8.21 & 2.29 & $\Gamma \mathrm{C}_{37} \mathrm{C}_{36} \mathrm{C}_{39} \mathrm{H}_{40}(21)+\Gamma \mathrm{C}_{38} \mathrm{C}_{36} \mathrm{C}_{41} \mathrm{H}_{42}(22)+\tau \mathrm{H}_{50} \mathrm{C}_{47} \mathrm{C}_{49} \mathrm{C}_{53}(23)$ \\
\hline 128 & 828 & 829 & 866 & 832 & 0.18 & 0.07 & 1.98 & 0.55 & $\Gamma \mathrm{C}_{37} \mathrm{C}_{36} \mathrm{C}_{39} \mathrm{H}_{40}(24)+\Gamma \mathrm{C}_{38} \mathrm{C}_{36} \mathrm{C}_{41} \mathrm{H}_{42}(24)+\tau \mathrm{H}_{50} \mathrm{C}_{47} \mathrm{C}_{49} \mathrm{C}_{53}(23)$ \\
\hline 129 & & & 855 & 821 & 0.33 & 0.13 & 3.11 & 0.87 & $\Gamma \mathrm{C}_{16} \mathrm{C}_{14} \mathrm{C}_{19} \mathrm{H}_{17}(16)$ \\
\hline 130 & 807 & 806 & 839 & 806 & 0.15 & 0.06 & 4.46 & 1.24 & $\Gamma \mathrm{C}_{48} \mathrm{C}_{46} \mathrm{C}_{51} \mathrm{H}_{52}(23)$ \\
\hline 131 & & & 835 & 802 & 0.55 & 0.22 & 4.60 & 1.28 & $\Gamma \mathrm{C}_{60} \mathrm{C}_{58} \mathrm{C}_{63} \mathrm{H}_{64}(37)+\tau \mathrm{H}_{62} \mathrm{C}_{59} \mathrm{C}_{61} \mathrm{C}_{65}(49)$ \\
\hline 132 & & & 811 & 779 & 1.11 & 0.44 & 2.95 & 0.82 & $\mathrm{VC}_{2} \mathrm{C}_{3}(15)$ \\
\hline 133 & 753 & 755 & 796 & 765 & 56.23 & 22.25 & 4.72 & 1.32 & $\Gamma \mathrm{N}_{9} \mathrm{C}_{1} \mathrm{C}_{5} \mathrm{H}_{10}(46)$ \\
\hline 134 & & & 780 & 749 & 12.36 & 4.89 & 13.29 & 3.71 & $\Gamma \mathrm{C}_{53} \mathrm{C}_{49} \mathrm{C}_{51} \mathrm{H}_{56}(10)$ \\
\hline 135 & & & 779 & 748 & 4.01 & 1.59 & 2.16 & 0.60 & $\Gamma \mathrm{C}_{16} \mathrm{C}_{14} \mathrm{C}_{19} \mathrm{H}_{17}(15)$ \\
\hline 136 & & & 776 & 746 & 65.62 & 25.97 & 5.83 & 1.63 & $\Gamma_{43} \mathrm{C}_{39} \mathrm{C}_{41} \mathrm{H}_{57}(12)$ \\
\hline 137 & & & 773 & 743 & 21.88 & 8.66 & 4.29 & 1.20 & $\mathrm{VS}_{31} \mathrm{C}_{32}(10)+\tau \mathrm{H}_{68} \mathrm{C}_{65} \mathrm{C}_{61} \mathrm{C}_{59}(19)+\tau \mathrm{N}_{28} \mathrm{C}_{58} \mathrm{C}_{60} \mathrm{C}_{59}(17)$ \\
\hline 138 & & & 751 & 722 & 11.66 & 4.61 & 1.18 & 0.33 & $\Gamma \mathrm{C}_{16} \mathrm{C}_{14} \mathrm{C}_{19} \mathrm{H}_{17}(27)+\Gamma \mathrm{C}_{19} \mathrm{C}_{16} \mathrm{C}_{22} \mathrm{H}_{20}(32)$ \\
\hline 139 & 698 & 699 & 747 & 718 & 36.27 & 14.35 & 18.70 & 5.22 & $\mathrm{VS}_{31} \mathrm{C}_{32}(23)$ \\
\hline 140 & & & 722 & 694 & 38.07 & 15.07 & 2.14 & 0.60 & $\tau \mathrm{C}_{39} \mathrm{C}_{37} \mathrm{C}_{43} \mathrm{C}_{41}(22)$ \\
\hline 141 & & & 718 & 690 & 17.69 & 7.00 & 1.81 & 0.50 & $\tau \mathrm{C}_{38} \mathrm{C}_{41} \mathrm{C}_{39} \mathrm{C}_{43}(15)+\tau \mathrm{C}_{36} \mathrm{C}_{38} \mathrm{C}_{43} \mathrm{C}_{41}(47)+\tau \mathrm{C}_{39} \mathrm{C}_{37} \mathrm{C}_{43} \mathrm{C}_{41}(20)$ \\
\hline 142 & & & 715 & 687 & 10.43 & 4.13 & 3.85 & 1.07 & $\tau \mathrm{C}_{46} \mathrm{C}_{48} \mathrm{C}_{53} \mathrm{C}_{51}(41)+\tau \mathrm{C}_{48} \mathrm{C}_{51} \mathrm{C}_{49} \mathrm{C}_{53}(10)+\tau \mathrm{C}_{49} \mathrm{C}_{47} \mathrm{C}_{53} \mathrm{C}_{51}(11)$ \\
\hline 143 & 669 & 670 & 699 & 672 & 10.10 & 4.00 & 0.87 & 0.24 & $\tau \mathrm{H}_{62} \mathrm{C}_{59} \mathrm{C}_{61} \mathrm{C}_{65}(10)+\tau \mathrm{H}_{68} \mathrm{C}_{65} \mathrm{C}_{61} \mathrm{C}_{59}(10)+\tau \mathrm{C}_{58} \mathrm{C}_{60} \mathrm{C}_{65} \mathrm{C}_{63}(45)$ \\
\hline 144 & 645 & 648 & 676 & 650 & 22.84 & 9.04 & 14.00 & 3.90 & $\beta \mathrm{N}_{27} \mathrm{C}_{32} \mathrm{~S}_{31}(24)$ \\
\hline 145 & & & 661 & 635 & 1.34 & 0.53 & 8.96 & 2.50 & $\beta \mathrm{C}_{48} \mathrm{C}_{51} \mathrm{C}_{53}(40)$ \\
\hline 146 & & & 635 & 610 & 0.38 & 0.15 & 5.67 & 1.58 & $\beta \mathrm{C}_{46} \mathrm{C}_{47} \mathrm{C}_{49}(18)+\beta \mathrm{C}_{48} \mathrm{C}_{51} \mathrm{C}_{53}(44)+\beta \mathrm{C}_{53} \mathrm{C}_{49} \mathrm{C}_{47}(13)$ \\
\hline 147 & & & 634 & 609 & 0.02 & 0.01 & 3.69 & 1.03 & $\beta \mathrm{C}_{36} \mathrm{C}_{38} \mathrm{C}_{41}(20)+\beta \mathrm{C}_{43} \mathrm{C}_{39} \mathrm{C}_{37}(37)$ \\
\hline 148 & 599 & 600 & 631 & 606 & 2.63 & 1.04 & 5.41 & 1.51 & $\beta \mathrm{C}_{58} \mathrm{C}_{60} \mathrm{C}_{63}(22)+\beta \mathrm{C}_{60} \mathrm{C}_{63} \mathrm{C}_{65}(33)+\beta \mathrm{C}_{65} \mathrm{C}_{61} \mathrm{C}_{59}(25)$ \\
\hline 149 & & & 620 & 596 & 7.12 & 2.82 & 6.14 & 1.71 & $\beta \mathrm{C}_{47} \mathrm{C}_{46} \mathrm{C}_{48}(14)$ \\
\hline 150 & & & 614 & 590 & 2.16 & 0.86 & 4.58 & 1.28 & $\Gamma \mathrm{S}_{31} \mathrm{~N}_{27} \mathrm{~N}_{28} \mathrm{C}_{32}(16)$ \\
\hline 151 & & & 601 & 577 & 2.74 & 1.09 & 1.97 & 0.55 & $\Gamma \mathrm{S}_{31} \mathrm{~N}_{27} \mathrm{~N}_{28} \mathrm{C}_{32}(36)$ \\
\hline 152 & 570 & 572 & 596 & 573 & 3.28 & 1.30 & 3.95 & 1.10 & $\Gamma \mathrm{S}_{31} \mathrm{~N}_{27} \mathrm{~N}_{28} \mathrm{C}_{32}(22)$ \\
\hline 153 & & & 583 & 560 & 9.60 & 3.80 & 1.59 & 0.44 & $\beta C_{2} C_{1} N_{9}(16)$ \\
\hline 154 & 529 & 528 & 551 & 529 & 10.98 & 4.34 & 2.72 & 0.76 & $\beta \mathrm{C}_{4} \mathrm{C}_{5} \mathrm{~N}_{9}(14)$ \\
\hline 155 & & & 540 & 519 & 8.50 & 3.36 & 1.25 & 0.35 & $\beta_{4} \mathrm{C}_{5} \mathrm{~N}_{9}(10)$ \\
\hline 156 & 501 & 500 & 520 & 500 & 18.61 & 7.37 & 3.14 & 0.87 & $\tau \mathrm{H}_{29} \mathrm{~N}_{28} \mathrm{C}_{58} \mathrm{C}_{60}(21)+\tau \mathrm{C}_{61} \mathrm{C}_{59} \mathrm{C}_{65} \mathrm{C}_{63}(11)+\Gamma \mathrm{S}_{31} \mathrm{~N}_{27} \mathrm{~N}_{28} \mathrm{C}_{32}(37)$ \\
\hline 157 & & & 512 & 492 & 8.15 & 3.22 & 4.03 & 1.12 & $\Gamma \mathrm{N}_{28} \mathrm{C}_{58} \mathrm{C}_{60} \mathrm{C}_{59}(18)$ \\
\hline 158 & 468 & 470 & 490 & 471 & 79.83 & 31.59 & 32.99 & 9.20 & $\tau \mathrm{H}_{29} \mathrm{~N}_{28} \mathrm{C}_{58} \mathrm{C}_{60}(56)$ \\
\hline 159 & & & 481 & 462 & 2.24 & 0.89 & 0.97 & 0.27 & $\beta \mathrm{C}_{22} \mathrm{C}_{19} \mathrm{C}_{16}(11)+\beta \mathrm{C}_{19} \mathrm{C}_{16} \mathrm{C}_{14}(10)$ \\
\hline 160 & & & 438 & 421 & 1.47 & 0.58 & 1.89 & 0.53 & $\beta C_{4} C_{3} C_{2}(29)$ \\
\hline 161 & & & 421 & 404 & 42.59 & 16.85 & 32.14 & 8.96 & $\tau \mathrm{H}_{30} \mathrm{~N}_{27} \mathrm{~N}_{26} \mathrm{C}_{3}(51)$ \\
\hline 162 & & & 419 & 403 & 2.75 & 1.09 & 1.57 & 0.44 & $\tau \mathrm{C}_{30} \mathrm{C}_{27} \mathrm{C}_{26} \mathrm{C}_{3}(30)+\tau \mathrm{C}_{39} \mathrm{C}_{37} \mathrm{C}_{43} \mathrm{C}_{41}(42)$ \\
\hline 163 & & & 418 & 402 & 0.43 & 0.17 & 0.27 & 0.07 & $\tau \mathrm{C}_{48} \mathrm{C}_{51} \mathrm{C}_{49} \mathrm{C}_{53}(37)+\tau \mathrm{C}_{49} \mathrm{C}_{47} \mathrm{C}_{53} \mathrm{C}_{51}(42)$ \\
\hline 164 & & & 417 & 401 & 0.32 & 0.13 & 1.95 & 0.54 & $\tau \mathrm{C}_{60} \mathrm{C}_{63} \mathrm{C}_{61} \mathrm{C}_{65}(35)+\tau \mathrm{C}_{60} \mathrm{C}_{63} \mathrm{C}_{61} \mathrm{C}_{65}(42)$ \\
\hline 165 & & 378 & 393 & 378 & 1.37 & 0.54 & 3.26 & 0.91 & $\beta \mathrm{C}_{3} \mathrm{C}_{2} \mathrm{C}_{11}(22)$ \\
\hline 166 & & & 371 & 356 & 1.37 & 0.54 & 11.20 & 3.12 & $\tau \mathrm{C}_{3} \mathrm{C}_{2} \mathrm{C}_{4} \mathrm{C}_{5}(10)+\Gamma \mathrm{C}_{11} \mathrm{C}_{1} \mathrm{C}_{3} \mathrm{C}_{2}(18)$ \\
\hline 167 & & & 361 & 347 & 22.77 & 9.01 & 3.92 & 1.09 & $\tau \mathrm{H}_{30} \mathrm{~N}_{27} \mathrm{~N}_{26} \mathrm{C}_{3}(15)+\tau \mathrm{C}_{2} \mathrm{C}_{3} \mathrm{~N}_{26} \mathrm{~N}_{27}(23)$ \\
\hline
\end{tabular}

https://biointerfaceresearch.com/ 
https://doi.org/10.33263/BRIAC114.1183311855

\begin{tabular}{|c|c|c|c|c|c|c|c|c|}
\hline 168 & 324 & 339 & 326 & 1.18 & 0.47 & 1.29 & 0.36 & $\beta \mathrm{C}_{60} \mathrm{C}_{58} \mathrm{~N}_{28}(23)+\beta \mathrm{N}_{28} \mathrm{C}_{32} \mathrm{~N}_{27}(10)$ \\
\hline 169 & & 323 & 310 & 7.49 & 2.96 & 3.33 & 0.93 & $\beta \mathrm{C}_{3} \mathrm{C}_{2} \mathrm{C}_{11}(14)$ \\
\hline 170 & & 310 & 298 & 3.32 & 1.32 & 3.53 & 0.98 & $\beta \mathrm{C}_{48} \mathrm{C}_{46} \mathrm{C}_{5}(11)+\tau \mathrm{C}_{1} \mathrm{~N}_{9} \mathrm{C}_{4} \mathrm{C}_{5}(14)$ \\
\hline 171 & & 293 & 282 & 2.20 & 0.87 & 2.20 & 0.61 & $\beta \mathrm{C}_{38} \mathrm{C}_{36} \mathrm{C}_{1}(14)+\beta \mathrm{C}_{48} \mathrm{C}_{46} \mathrm{C}_{5}(12)$ \\
\hline 172 & & 281 & 270 & 3.75 & 1.49 & 1.38 & 0.38 & $\beta \mathrm{C}_{22} \mathrm{C}_{19} \mathrm{C}_{16}(11)$ \\
\hline 173 & & 263 & 253 & 1.29 & 0.51 & 2.29 & 0.64 & $\beta \mathrm{C}_{22} \mathrm{C}_{19} \mathrm{C}_{16}(23)+\beta \mathrm{C}_{19} \mathrm{C}_{16} \mathrm{C}_{14}(21)$ \\
\hline 174 & & 249 & 239 & 0.27 & 0.11 & 0.30 & 0.08 & $\tau \mathrm{H}_{23} \mathrm{C}_{22} \mathrm{C}_{19} \mathrm{C}_{16}(52)$ \\
\hline 175 & 232 & 243 & 233 & 1.17 & 0.46 & 4.44 & 1.24 & $\tau \mathrm{C}_{60} \mathrm{C}_{63} \mathrm{C}_{61} \mathrm{C}_{65}(16)$ \\
\hline 176 & & 239 & 230 & 1.88 & 0.74 & 1.23 & 0.34 & $\tau \mathrm{H}_{23} \mathrm{C}_{22} \mathrm{C}_{19} \mathrm{C}_{16}(25)$ \\
\hline 177 & & 229 & 220 & 0.42 & 0.17 & 3.93 & 1.10 & $\beta \mathrm{C}_{22} \mathrm{C}_{19} \mathrm{C}_{16}(20)$ \\
\hline 178 & 207 & 217 & 208 & 0.42 & 0.17 & 1.62 & 0.45 & $\beta \mathrm{H}_{23} \mathrm{C}_{22} \mathrm{C}_{19} \mathrm{C}_{16}(11)$ \\
\hline 179 & & 203 & 195 & 0.70 & 0.28 & 7.00 & 1.95 & $\beta \mathrm{N}_{27} \mathrm{C}_{32} \mathrm{~S}_{31}(12)$ \\
\hline 180 & & 183 & 176 & 0.59 & 0.23 & 1.77 & 0.49 & $\beta \mathrm{C}_{38} \mathrm{C}_{36} \mathrm{C}_{1}(14)+\beta \mathrm{N}_{48} \mathrm{C}_{46} \mathrm{~S}_{5}(11)$ \\
\hline 181 & 155 & 161 & 155 & 8.17 & 3.23 & 5.69 & 1.59 & $\beta \mathrm{C}_{60} \mathrm{C}_{58} \mathrm{~N}_{28}(10)+\beta \mathrm{C}_{58} \mathrm{~N}_{28} \mathrm{C}_{32}(15)$ \\
\hline 182 & & 142 & 136 & 1.82 & 0.72 & 2.33 & 0.65 & $\tau \mathrm{C}_{32} \mathrm{~N}_{27} \mathrm{~N}_{26} \mathrm{C}_{3}(18)+\tau \mathrm{C}_{1} \mathrm{C}_{2} \mathrm{C}_{3} \mathrm{~N}_{26}(12)$ \\
\hline 183 & & 121 & 116 & 2.33 & 0.92 & 0.37 & 0.10 & $\tau \mathrm{N}_{28} \mathrm{C}_{32} \mathrm{~N}_{27} \mathrm{~N}_{26}(14)$ \\
\hline 184 & & 116 & 111 & 0.29 & 0.11 & 1.53 & 0.43 & $\beta \mathrm{C}_{3} \mathrm{C}_{2} \mathrm{C}_{11}(10)+\tau \mathrm{N}_{28} \mathrm{C}_{32} \mathrm{~N}_{27} \mathrm{~N}_{26}(11)$ \\
\hline 185 & & 95 & 91 & 0.21 & 0.08 & 0.90 & 0.25 & $\tau \mathrm{C}_{22} \mathrm{C}_{19} \mathrm{C}_{16} \mathrm{C}_{14}(38)+\tau \mathrm{C}_{19} \mathrm{C}_{16} \mathrm{C}_{14} \mathrm{C}_{11}(31)$ \\
\hline 186 & & 86 & 83 & 0.08 & 0.03 & 2.52 & 0.70 & $\tau \mathrm{C}_{1} \mathrm{~N}_{9} \mathrm{C}_{5} \mathrm{C}_{46}(16)+\tau \mathrm{C}_{5} \mathrm{~N}_{9} \mathrm{C}_{1} \mathrm{C}_{36}(16)$ \\
\hline 187 & & 79 & 76 & 0.26 & 0.10 & 1.01 & 0.28 & $\tau \mathrm{H}_{22} \mathrm{C}_{19} \mathrm{C}_{16} \mathrm{C}_{14}(17)$ \\
\hline 188 & 71 & 73 & 70 & 0.10 & 0.04 & 2.02 & 0.56 & $\Gamma \mathrm{C}_{1} \mathrm{C}_{36} \mathrm{C}_{38} \mathrm{C}_{37}(15)+\tau \mathrm{C}_{5} \mathrm{~N}_{9} \mathrm{C}_{1} \mathrm{C}_{36}(10)$ \\
\hline 189 & & 51 & 49 & 0.10 & 0.04 & 9.10 & 2.54 & $\beta \mathrm{C}_{46} \mathrm{C}_{5} \mathrm{~N}_{9}(11)+\tau \mathrm{C}_{38} \mathrm{C}_{36} \mathrm{C}_{1} \mathrm{~N}_{9}(18)$ \\
\hline 190 & & 49 & 47 & 0.10 & 0.04 & 6.54 & 1.82 & $\tau \mathrm{C}_{38} \mathrm{C}_{36} \mathrm{C}_{1} \mathrm{~N}_{9}(42)+\tau \mathrm{C}_{58} \mathrm{~N}_{28} \mathrm{C}_{32} \mathrm{~N}_{27}(11)+\tau \mathrm{C}_{1} \mathrm{~N}_{9} \mathrm{C}_{5} \mathrm{C}_{46}(11)$ \\
\hline 191 & & 43 & 41 & 0.03 & 0.01 & 1.76 & 0.49 & $\beta \mathrm{C}_{36} \mathrm{C}_{1} \mathrm{~N}_{9}(15)+\tau \mathrm{C}_{38} \mathrm{C}_{36} \mathrm{C}_{1} \mathrm{~N}_{9}(19)+\tau \mathrm{C}_{58} \mathrm{~N}_{28} \mathrm{C}_{32} \mathrm{~N}_{27}(10)$ \\
\hline 192 & & 36 & 35 & 0.52 & 0.21 & 0.61 & 0.17 & $\beta C_{32} \mathrm{~N}_{27} \mathrm{~N}_{26}(11)+\beta \mathrm{N}_{27} \mathrm{~N}_{26} \mathrm{C}_{3}(11)+\tau \mathrm{C}_{58} \mathrm{~N}_{28} \mathrm{C}_{32} \mathrm{~N}_{27}(10)$ \\
\hline 193 & & 32 & 31 & 0.77 & 0.30 & 4.66 & 1.30 & $\tau \mathrm{C}_{48} \mathrm{~N}_{46} \mathrm{C}_{5} \mathrm{~N}_{9}(16)+\tau \mathrm{C}_{32} \mathrm{~N}_{28} \mathrm{C}_{58} \mathrm{C}_{60}(16)+\tau \mathrm{C}_{32} \mathrm{~N}_{27} \mathrm{~N}_{26} \mathrm{C}_{3}(12)$ \\
\hline 194 & & 28 & 27 & 0.40 & 0.16 & 9.35 & 2.61 & $\tau \mathrm{C}_{48} \mathrm{C}_{46} \mathrm{C}_{5} \mathrm{~N}_{9}(55)+\tau \mathrm{C}_{16} \mathrm{C}_{14} \mathrm{C}_{11} \mathrm{C}_{2}(16)$ \\
\hline 195 & & 25 & 24 & 0.36 & 0.14 & 2.05 & 0.57 & $\beta \mathrm{C}_{58} \mathrm{~N}_{28} \mathrm{C}_{32}(10)+\tau \mathrm{C}_{32} \mathrm{~N}_{28} \mathrm{C}_{58} \mathrm{C}_{60}(13)+\tau \mathrm{C}_{16} \mathrm{C}_{14} \mathrm{C}_{11} \mathrm{C}_{2}(45)$ \\
\hline 196 & & 19 & 18 & 0.44 & 0.18 & 1.74 & 0.48 & $\tau \mathrm{C}_{48} \mathrm{C}_{46} \mathrm{C}_{5} \mathrm{~N}_{9}(10)+\tau \mathrm{C}_{32} \mathrm{~N}_{27} \mathrm{~N}_{26} \mathrm{C}_{3}(22)$ \\
\hline 197 & & 18 & 17 & 2.10 & 0.83 & 4.53 & 1.26 & $\tau \mathrm{C}_{28} \mathrm{C}_{32} \mathrm{~N}_{27} \mathrm{~N}_{26}(13)+\tau \mathrm{C}_{2} \mathrm{C}_{3} \mathrm{~N}_{26} \mathrm{~N}_{27}(13)+\Gamma \mathrm{C}_{1} \mathrm{C}_{2} \mathrm{~N}_{9} \mathrm{C}_{3}(10)$ \\
\hline 198 & & 14 & 13 & 0.0318 & 0.0126 & 2.0202 & 0.5634 & $\tau \mathrm{C}_{32} \mathrm{~N}_{27} \mathrm{~N}_{26} \mathrm{C}_{3}(13)+\tau \mathrm{C}_{58} \mathrm{~N}_{28} \mathrm{C}_{32} \mathrm{~N}_{27}(15)+\tau \mathrm{C}_{1} \mathrm{C}_{2} \mathrm{C}_{3} \mathrm{~N}_{26}(20)$ \\
\hline
\end{tabular}

$v$ : Stretching, $\beta$ : in-plane-bending, $\Gamma$ : out-of-plane bending, $\tau$ : Torsion, vw: very week, w: week, m: medium, s: strong, vs: very strong,

a Scaling factor: 0.9608 ,

${ }^{\mathrm{b}}$ Relative IR absorption intensities normalized with highest peak absorption equal to 100 ,

${ }^{\mathrm{c}}$ Relative Raman intensities calculated and normalized to 100 ,

d Total energy distribution calculated at B3LYP/6-311++G(d,p) level. 
Table 3. The NLO measurements of 3-PDPPPHC.

\begin{tabular}{l|l|l|l} 
Parameter & Hyperpolarizability & Parameter & Polarizability \\
\hline$\beta_{\mathrm{xxx}}$ & 27.0596 & $\alpha_{\mathrm{xx}}$ & -195.3236 \\
\hline$\beta_{\mathrm{yyy}}$ & 60.4279 & $\alpha_{\mathrm{yy}}$ & -210.9731 \\
\hline$\beta_{\mathrm{zzz}}$ & -2.5280 & $\alpha_{\mathrm{zz}}$ & -206.3976 \\
\hline$\beta_{\mathrm{xyy}}$ & -71.6706 & $\alpha_{\mathrm{xy}}$ & 12.9496 \\
\hline$\beta_{\mathrm{xxy}}$ & 20.4510 & $\alpha_{\mathrm{xz}}$ & 3.6875 \\
\hline$\beta_{\mathrm{xxz}}$ & -6.5713 & $\alpha_{\mathrm{yz}}$ & -7.3381 \\
\hline$\beta_{\mathrm{xzz}}$ & 3.7648 & $\alpha_{\mathrm{o}}(\mathrm{esu})$ & $0.32671 \times 10^{-30} \mathrm{esu}$ \\
\hline$\beta_{\mathrm{yzz}}$ & 17.0146 & & \\
\hline$\beta_{\mathrm{yyz}}$ & 39.1729 & & \\
\hline$\beta_{\mathrm{xyz}}$ & -24.8329 & & \\
\hline$\beta_{0}(\mathrm{esu})$ & $9.52518 \mathrm{X} 10^{-30} \mathrm{esu}$ & &
\end{tabular}

Standard value for urea $\left(\boldsymbol{\mu}=1.3732\right.$ Debye, $\left.\boldsymbol{\beta}_{0}=0.3728 \times 10^{-30} \mathrm{esu}\right)$ : esu-electrostatic unit

Table 4. The NBO analysis of 3-PDPPPHC.

\begin{tabular}{|c|c|c|c|c|c|c|c|}
\hline Type & Donor NBO (i) & ED/e & Acceptor NBO (j) & ED/e & $\mathrm{E}^{(2)} \mathrm{KJ} / \mathrm{mol}$ & E(j)-E(i) a.u. & $\mathbf{F}(\mathbf{i}, \mathbf{j})$ a.u. \\
\hline$\pi-\pi^{*}$ & BD (2) C37 - C39 & 1.66588 & BD*(2) C36 - C38 & 0.35003 & 86.94 & 0.28 & 0.069 \\
\hline \multirow[t]{2}{*}{$\pi-\pi^{*}$} & BD (2) C41 - C43 & 1.66448 & $\mathrm{BD} *(2) \mathrm{C} 36-\mathrm{C} 38$ & 0.35003 & 83.97 & 0.28 & 0.067 \\
\hline & & & $\mathrm{BD}^{*}(2) \mathrm{C} 51-\mathrm{C} 53$ & 0.33318 & 87.11 & 0.28 & 0.068 \\
\hline \multirow[t]{2}{*}{$\pi-\pi^{*}$} & BD (2) C47 - C49 & 1.66656 & $\mathrm{BD}^{*}(2) \mathrm{C} 46-\mathrm{C} 48$ & 0.34829 & 87.03 & 0.28 & 0.069 \\
\hline & & & $\mathrm{BD}^{*}(2) \mathrm{C} 51-\mathrm{C} 53$ & 0.33318 & 84.39 & 0.28 & 0.067 \\
\hline \multirow[t]{2}{*}{$\pi-\pi^{*}$} & BD (2) C51 - C53 & 1.66295 & $\mathrm{BD}^{*}(2) \mathrm{C} 46-\mathrm{C} 48$ & 0.34829 & 83.72 & 0.28 & 0.067 \\
\hline & & & $\mathrm{BD}^{*}(2) \mathrm{C} 47$ - C49 & 0.32671 & 85.44 & 0.28 & 0.068 \\
\hline$\pi-\pi^{*}$ & BD (2) C58 - C59 & 1.65941 & BD*(2) C61 - C65 & 0.34741 & 88.7 & 0.29 & 0.07 \\
\hline $\mathrm{n}-\sigma^{*}$ & LP (1) N26 & 1.91379 & $\mathrm{BD} *(1) \mathrm{C} 2-\mathrm{C} 3$ & 0.05081 & 63.14 & 0.75 & 0.096 \\
\hline \multirow[t]{2}{*}{$\mathrm{n}-\pi^{*}$} & LP (1) N27 & 1.67942 & $\mathrm{BD} *(2) \mathrm{C} 3-\mathrm{N} 26$ & 0.17095 & 112.93 & 0.31 & 0.084 \\
\hline & & & $\mathrm{BD}^{*}(1) \mathrm{S} 31-\mathrm{C} 32$ & 0.44774 & 238.28 & 0.23 & 0.106 \\
\hline $\mathrm{n}-\sigma^{*}$ & LP (1) N28 & 1.68391 & BD*(1) S31 - C32 & 0.44774 & 224.26 & 0.22 & 0.1 \\
\hline $\mathrm{n}-\sigma^{*}$ & LP (2) S31 & 1.86707 & $\mathrm{BD}^{*}(1) \mathrm{N} 27-\mathrm{C} 32$ & 0.0695 & 55.48 & 0.59 & 0.08 \\
\hline$\pi^{*}-\pi^{*}$ & $\mathrm{BD} *(2) \mathrm{C} 58-\mathrm{C} 59$ & 0.40213 & $\mathrm{BD}^{*}(2) \mathrm{C} 61-\mathrm{C} 65$ & 0.34741 & 1285.12 & 0.01 & 0.081 \\
\hline
\end{tabular}

Table 5. The Physico-Chemical properties of 3-PDPPPHC.

\begin{tabular}{l|l} 
Parameters & Values \\
\hline HOMO & $-5.249 \mathrm{eV}$ \\
\hline LUMO & $-0.951 \mathrm{eV}$ \\
\hline Energy gap & $4.298 \mathrm{eV}$ \\
\hline HOMO-1 & $-5.527 \mathrm{eV}$ \\
\hline LUMO+1 & $-0.368 \mathrm{eV}$ \\
\hline Ionization potential $(\mathrm{IP})$ & $5.249 \mathrm{eV}$ \\
\hline Electron affinity $(\mathrm{EA})$ & $0.951 \mathrm{eV}$ \\
\hline Electrophilicity Index $(\omega)$ & 1.118 \\
\hline Chemical Potential $(\mu)$ & 3.101 \\
\hline Electro negativity $(\chi)$ & -3.101 \\
\hline Hardness $(\eta)$ & -4.298
\end{tabular}

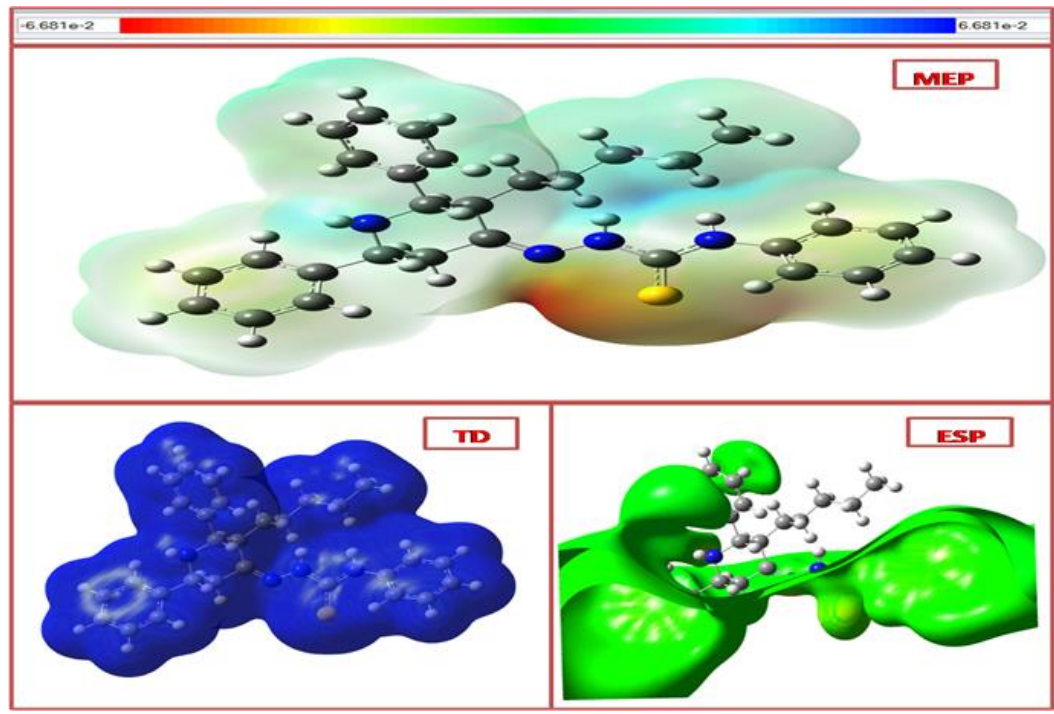

Figure 6. Electrostatic potential (ESP), total density (TD) and the molecular electrostatic potential (MEP) map in gas phase of 3-PDPPPHC. 


\subsection{Mulliken atomic charges.}

Mulliken atomic charge calculation has an important role in applying quantum chemical calculation to the molecular system since atomic charges affect the dipole moment, molecular polarizability, electronic structure, and many more molecular systems properties. In the present study, the Mulliken charges were calculated by DFT/B3LYP/6-311++G(d,p) basis set. The calculated Mulliken charge values are listed in Table 6 and are plotted in Fig. 7. The C22/C32 atoms have the highest negative/positive charges, respectively, among the other atoms in the 3-PDPPPHC molecule due to the resonance. The Nitrogen and sulfur atoms have negative charges and all hydrogen atoms having net positive charges in the present system.

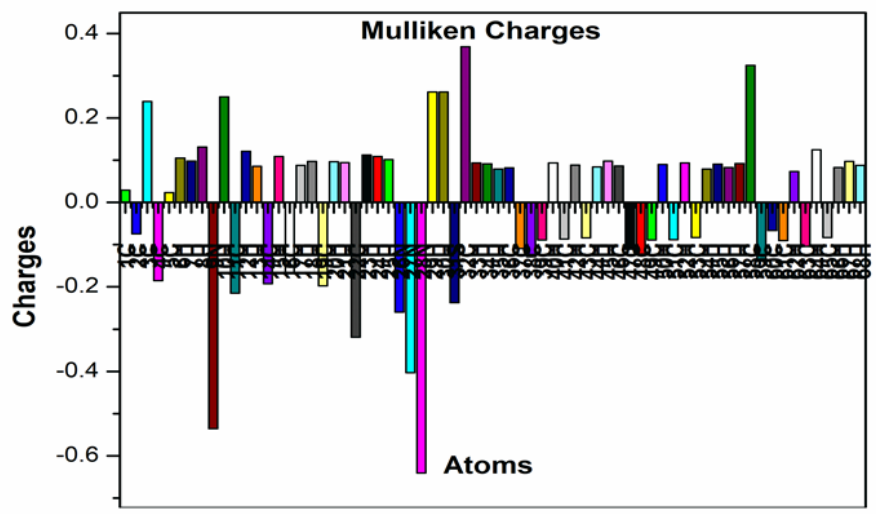

Figure 7. The Mulliken atomic charges of 3-PDPPPHC.

Table 6. The Mulliken atomic charges of 3-PDPPPHC.

\begin{tabular}{l|l|l|l|l|l} 
Atom & Charges & Atom & Charges & Atom & Charges \\
\hline $1 \mathrm{C}$ & 0.02905 & $24 \mathrm{H}$ & 0.10917 & $47 \mathrm{C}$ & -0.1103 \\
\hline $2 \mathrm{C}$ & -0.0741 & $25 \mathrm{H}$ & 0.10188 & $48 \mathrm{C}$ & -0.1221 \\
\hline $3 \mathrm{C}$ & 0.23892 & $26 \mathrm{~N}$ & -0.2598 & $49 \mathrm{C}$ & -0.0891 \\
\hline $4 \mathrm{C}$ & -0.1852 & $27 \mathrm{~N}$ & -0.403 & $50 \mathrm{H}$ & 0.08993 \\
\hline $5 \mathrm{C}$ & 0.02328 & $28 \mathrm{~N}$ & -0.6404 & $51 \mathrm{C}$ & -0.0878 \\
\hline $6 \mathrm{H}$ & 0.10552 & $29 \mathrm{H}$ & 0.26156 & $52 \mathrm{H}$ & 0.0935 \\
\hline $7 \mathrm{H}$ & 0.09778 & $30 \mathrm{H}$ & 0.26132 & $53 \mathrm{C}$ & -0.0834 \\
\hline $8 \mathrm{H}$ & 0.13144 & $31 \mathrm{~S}$ & -0.2371 & $54 \mathrm{H}$ & 0.07883 \\
\hline $9 \mathrm{~N}$ & -0.5359 & $32 \mathrm{C}$ & 0.36851 & $55 \mathrm{H}$ & 0.09093 \\
\hline $10 \mathrm{H}$ & 0.2498 & $33 \mathrm{H}$ & 0.09341 & $56 \mathrm{H}$ & 0.08292 \\
\hline $11 \mathrm{C}$ & -0.2148 & $34 \mathrm{H}$ & 0.09128 & $57 \mathrm{H}$ & 0.09221 \\
\hline $12 \mathrm{H}$ & 0.12148 & $35 \mathrm{H}$ & 0.07892 & $58 \mathrm{C}$ & 0.32464 \\
\hline $13 \mathrm{H}$ & 0.08562 & $36 \mathrm{C}$ & 0.08201 & $59 \mathrm{C}$ & -0.1392 \\
\hline $14 \mathrm{C}$ & -0.1921 & $37 \mathrm{C}$ & -0.109 & $60 \mathrm{C}$ & -0.0665 \\
\hline $15 \mathrm{H}$ & 0.109 & $38 \mathrm{C}$ & -0.1287 & $61 \mathrm{C}$ & -0.09 \\
\hline $16 \mathrm{C}$ & -0.1669 & $39 \mathrm{C}$ & -0.0888 & $62 \mathrm{H}$ & 0.07336 \\
\hline $17 \mathrm{H}$ & 0.08814 & $40 \mathrm{H}$ & 0.09359 & $63 \mathrm{C}$ & -0.1038 \\
\hline $18 \mathrm{H}$ & 0.09697 & $41 \mathrm{C}$ & -0.0866 & $64 \mathrm{H}$ & 0.12507 \\
\hline $19 \mathrm{C}$ & -0.1976 & $42 \mathrm{H}$ & 0.08828 & $65 \mathrm{C}$ & -0.0832 \\
\hline $20 \mathrm{H}$ & 0.09682 & $43 \mathrm{C}$ & -0.0836 & $66 \mathrm{H}$ & 0.08265 \\
\hline $21 \mathrm{H}$ & 0.09424 & $44 \mathrm{H}$ & 0.08443 & $67 \mathrm{H}$ & 0.0974 \\
\hline $22 \mathrm{C}$ & -0.3193 & $45 \mathrm{H}$ & 0.09818 & $68 \mathrm{H}$ & 0.0875 \\
\hline $23 \mathrm{H}$ & 0.1123 & $46 \mathrm{C}$ & 0.08639 & &
\end{tabular}

\subsection{Thermodynamic properties.}

Based on the vibrational analysis carried out at the B3LYP/6-311++G(d,p) level, the standard statistical thermodynamic functions such as heat capacity (Cp), entropy (S), and enthalpy changes $(\Delta \mathrm{H})$ are calculated for the present molecule. The values are listed in Table 7. It can be observed that these thermodynamic functions are increasing with temperature. The obvious reason for this almost linear increase is the increase in the molecule's internal energy 
in accordance with the kinetic theory of gases [55]. The correlation equations between thermodynamic functions and temperatures were fitted by quadratic formula. The corresponding fitting factors $\left(\mathrm{R}^{2}\right)$ for these thermodynamic properties are found to be 0.99878 , 0.99998, and 0.99952, respectively. The corresponding correlation graphs are shown in Fig. 8.

$$
\begin{gathered}
\mathrm{C}^{0}{ }_{\mathrm{p} . \mathrm{m}}=-0.77064+0.49207 \mathrm{~T}-1.90845 \times 10^{-4} \mathrm{~T}^{2}\left(\mathrm{R}^{2}=0.99878\right) \\
\mathrm{S}^{0}{ }_{\mathrm{m}}=78.34872+0.48239 \mathrm{~T}-8.82755 \times 10^{-5} \mathrm{~T}^{2}\left(\mathrm{R}^{2}=0.99998\right) \\
\mathrm{H}^{0}{ }_{\mathrm{m}}=-4.65157+0.04631 \mathrm{~T}+1.42948 \times 10^{-4} \mathrm{~T}^{2}\left(\mathrm{R}^{2}=0.99952\right)
\end{gathered}
$$

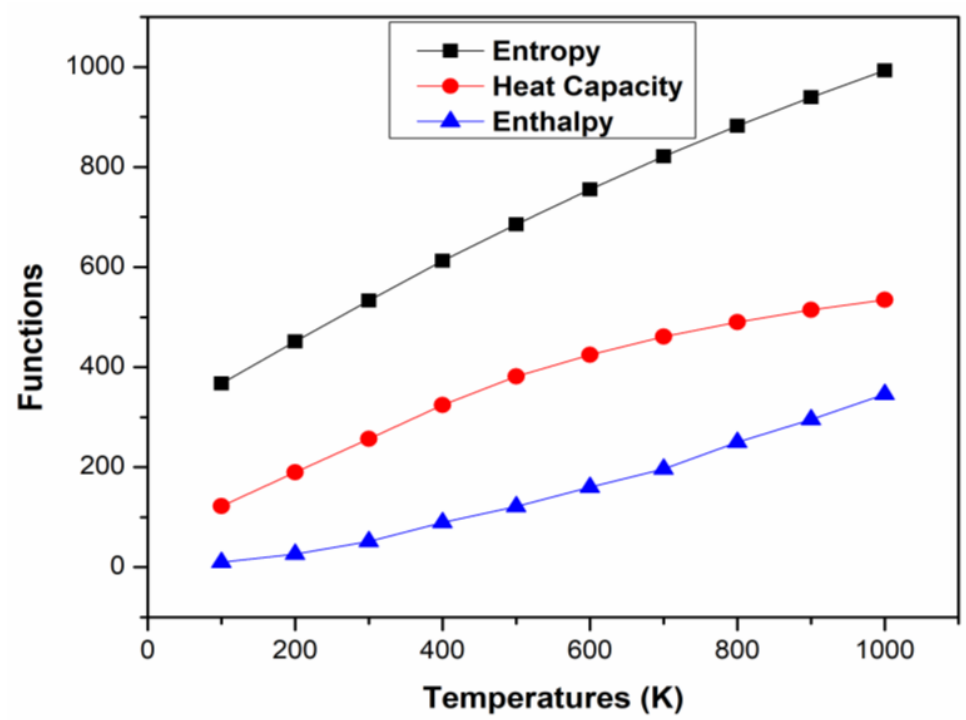

Figure 8. The thermodynamic properties at different temperatures of 3-PDPPPHC.

Table 7. The Thermodynamic properties at different temperatures of 3-PDPPPHC.

\begin{tabular}{l|c|c|c}
$\mathbf{T}$ & $\mathbf{S}(\mathbf{J} / \mathbf{m o l} . \mathbf{K})$ & $\mathbf{C p}(\mathbf{J} / \mathbf{m o l} . \mathbf{K})$ & $\mathbf{d d H}(\mathbf{k J} / \mathbf{m o l})$ \\
\hline 100 & 367.21 & 122.43 & 9.87 \\
\hline 200 & 451.17 & 189.58 & 26.22 \\
\hline 300 & 533.29 & 256.41 & 51.47 \\
\hline 400 & 612.32 & 324.51 & 89.12 \\
\hline 500 & 685.21 & 381.24 & 121.18 \\
\hline 600 & 755.02 & 424.81 & 160.37 \\
\hline 700 & 821.71 & 461.23 & 196.68 \\
\hline 800 & 882.51 & 490.24 & 249.68 \\
\hline 900 & 939.72 & 514.31 & 295.45 \\
\hline 1000 & 992.91 & 534.19 & 345.72
\end{tabular}

\subsection{Molecular docking studies.}

The dock, glide energy, and hydrogen bonding interactions of the title compound and co-crystallized ligand are given in Table 8 . A view of the X-ray crystal structure of the title compound in the Beta-lactamase Receptor active site showing the key hydrogen contacts between inhibitor and enzyme is depicted in Fig. 9. The co-crystallized ligand in the Betalactamase Receptor active site showing the key hydrogen contacts between inhibitor and enzyme is depicted in Fig. 10. The surface diagram showing the title compound docked at Betalactamase Receptor's active site is depicted in Fig. 11.

X-ray crystal structures confirmed the expected binding mode. Considering binding orientation and electronic properties enabled optimization to Piperidone as a more potent second-generation lead.

The title compound is shown to be an effective inhibitor. The amide group in the GLY286 interacts with the carbonyl group's oxygen atom at a distance of $2.8 \& 3.0 \AA$. The cocrystallized ligand also docked well, and it shows better interactions with residues GLY and 
THR, respectively. The results show that the title compound has better binding energy, and the co-crystallized ligand has comparable interactions.

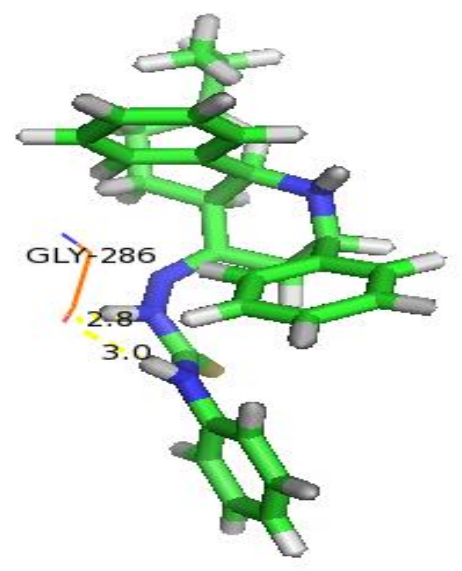

Figure 9. The title compound in the Beta-lactamase Receptor active site showing the key hydrogen contacts between Piperidone inhibitor and enzyme.

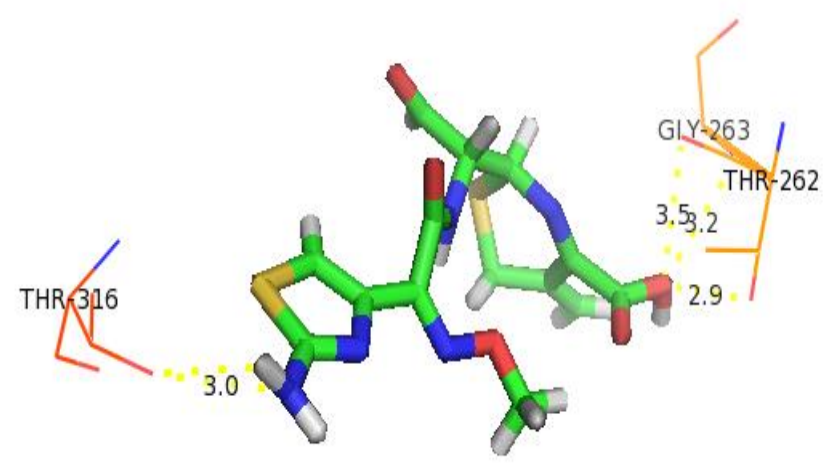

Figure 10. The co-crystallized ligand (dexamethasone) in the Beta-lactamase Receptor active site showing the key hydrogen contacts between inhibitor and enzyme.

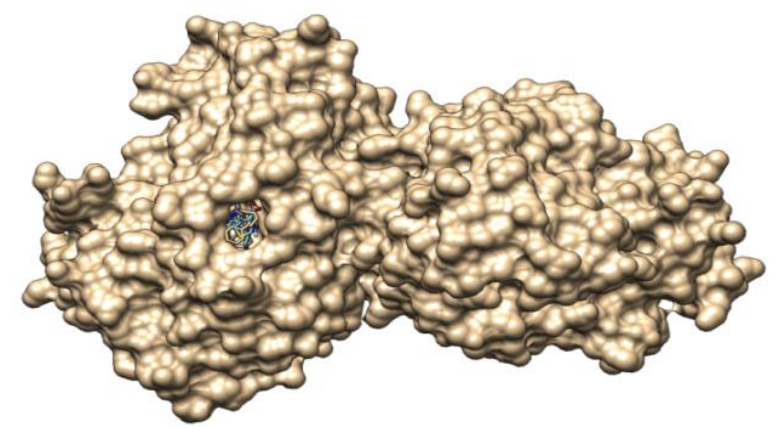

Figure 11. Surface diagram showing the Piperidone docked at the active site of beta-lactamase Receptor.

Table 8. Hydrogen bond interactions of Piperidone with amino acids at the active site of Beta-lactamase

\begin{tabular}{|c|c|c|c|c|}
\hline \multirow[t]{2}{*}{ Compound } & $\begin{array}{l}\text { Docking } \\
\text { Score }\end{array}$ & \multicolumn{3}{|c|}{ Hydrogen Bonding Interactions } \\
\hline & & Donor & Acceptor & Distance $(\AA)$ \\
\hline Piperidone & -6.1 & $\begin{array}{l}\mathrm{N}-\mathrm{H} \\
\mathrm{N}-\mathrm{H}\end{array}$ & O[GLY-286 & $\begin{array}{l}2.8 \\
3.0 \\
\end{array}$ \\
\hline & & O-H[THR263] & $\mathrm{O}^{*}$ & $\begin{array}{l}3.2 \\
2.9 \\
\end{array}$ \\
\hline Co-Crystal & -5.4 & N-H[THR316] & $\mathrm{O}^{*}$ & 3.0 \\
\hline & & O-H[GLY263] & $\mathrm{O}^{*}$ & 3.5 \\
\hline
\end{tabular}

* Ligand 
Table 9. Prediction of ADME/Tox.

\begin{tabular}{l|l} 
ID & Value \\
\hline BBB & 7.65083 \\
\hline Buffer_solubility_mg_L & 1.63674 \\
\hline Caco2 & 36.2157 \\
\hline CYP_3A4_substrate & Substrate \\
\hline HIA & 95.447711 \\
\hline MDCK & 18.6595 \\
\hline Plasma_Protein_Binding & 87.031791 \\
\hline Water_solubility_mg_L & 0.000931924 \\
\hline Skin_Permeability & -1.79587 \\
\hline SKlogD_value & 5.71791 \\
\hline SKlogP_value & 7.06189 \\
\hline SKlogS_buffer & -5.45874 \\
\hline SKlogS_pure & -8.70334 \\
-blood-brain barrier penetration \\
-Human intestinal absorption
\end{tabular}

\subsection{ADME analysis.}

In drug discovery, physicochemical properties were seen to find the vital properties affecting the biological functions (ADME). In this analysis, some important physicochemical properties were given in Table 9. The concept of absorption, distribution, metabolism, and excretion (ADME) shows small molecules' toxicity levels [56]. Drug discovery in silico method has been used to predict pharmacokinetic properties for instant ADMET accurately.

\section{Conclusions}

The FT-IR and FT-Raman spectra of 3-PDPPPHC have been recorded and analyzed for the first time. The detailed interpretations of the vibrational spectra have been carried out. The optimized geometrical parameters were calculated and compared with a structurally related molecule, which shows the chair conformation. The calculated and experimental results of all the fundamental vibrational modes of 3-PDPPPHC are examined with TED contribution. Besides, the first hyperpolarizability value of the molecule is high, i.e., twenty-six times greater than that of urea; hence, the molecule's NLO activity will also be proportionately high. The NBO result reflects more hyperconjugative interaction energy during $\pi$-electron transfer within $\pi-\pi^{*}$ interaction, and it leads that the molecule becomes more active. The lowering of the HOMO-LUMO energy gap value has a substantial influence on the ICT and bioactivity of the molecule. The Mulliken atomic charges were calculated and analyzed. The MEP surface predicts the nucleophilic and electrophilic reaction sites of the molecule. The thermodynamic properties such as heat capacity, entropy, and enthalpy at different temperatures were also calculated. Molecular docking results show that the title compound having better binding energy, and the co-crystallized ligand has comparable interactions.

\section{Funding}

This research received no external funding.

\section{Acknowledgments}

This research has no acknowledgment. 


\section{Conflicts of Interest}

\section{The authors declare no conflict of interest.}

\section{References}

1. Khan, S.A.; Kumar, P.; Joshi, R.; Iqbal, P.F.; Saleem, K. Synthesis and in vitro antibacterial activity of new steroidal thiosemicarbazone derivatives. European Journal of Medicinal Chemistry 2008, 43, 2029-2034, http://dx.doi.org/10.1016/j.ejmech.2007.12.004.

2. De Araújo Neto, L.N.; de Lima M do, C.A.; de Oliveira, J.F.; de Souza, E.R.; Feitosa Machado, S.E.; de Souza Lima, G.M. Thiophene-thiosemicarbazone derivative (L10) exerts antifungal activity mediated by oxidative stress and apoptosis in C. albicans. Chemico-Biological Interactions 2020, 320, http://dx.doi.org/10.1016/j.cbi.2020.109028.

3. De Oliveira, R.B.; de Souza-Fagundes, E.M.; Soares, R.P.P.; Andrade, A.A.; Krettli, A.U.; Zani, C.L. Synthesis and antimalarial activity of semicarbazone and thiosemicarbazone derivatives. European Journal of Medicinal Chemistry 2008, 43, 1983-1988, http://dx.doi.org/10.1016/j.ejmech.2007.11.012.

4. Matsa, R.; Makam, P.; Kaushik, M.; Hoti, S.L.; Kannan, T. Thiosemicarbazone derivatives: Design, synthesis and in vitro antimalarial activity studies. European Journal of Pharmaceutical Sciences 2019, 137, http://dx.doi.org/10.1016/j.ejps.2019.104986.

5. Ameryckx, A.; Pochet, L.; Wang, G.; Yildiz, E.; Saadi, B.E.; Wouters, J. Pharmacomodulations of the benzoyl-thiosemicarbazide scaffold reveal antimicrobial agents targeting d-alanyl-d-alanine ligase in bacterio. European Journal of Medicinal Chemistry 200, http://dx.doi.org/10.1016/j.ejmech.2020.112444.

6. Zhang, X.; Qi, F.; Wang, S.; Song, J.; Huang, J. Synthesis, structure, in silico ADME evaluation and in vitro antioxidant of (E)-N-(4-ethylphenyl)-2-(isomeric methylbenzylidene) thiosemicarbazone derivatives. Journal of Molecular Structure 2020, 1199, http://dx.doi.org/10.1016/j.molstruc.2019.126972.

7. Afrasiabi, Z.; Sinn, E.; Kulkarni, P.P.; Ambike, V.; Padhye, S.; Deobagakar, D. Synthesis and characterization of copper(II) complexes of 4-alkyl/aryl-1,2-naphthoquinones thiosemicarbazones derivatives as potent DNA cleaving agents. Inorganica Chimica Acta 2005, 358, 2023-2030, http://dx.doi.org/10.1016/j.ica.2004.12.042.

8. Song, J.; Pan, R.; Li, G.; Su, W.; Song, X.; Li, J. Synthesis and anticancer activities of thiosemicarbazones derivatives of thiochromanones and related scaffolds. Medicinal Chemistry Research 2020, 5, 630-642, http://dx.doi.org/10.1007/s00044-020-02503-w.

9. He, Z.; Qiao, H.; Yang, F.; Zhou, W.; Gong, Y.; Zhang, X. Novel thiosemicarbazone derivatives containing indole fragment as potent and selective anticancer agent. European Journal of Medicinal Chemistry 2019, 184, http://dx.doi.org/10.1016/j.ejmech.2019.111764.

10. Taroua, M.; Ribuot, C.; Péra, M.; Taillandier, G.; Fatome, M.; Laval, J. New $\alpha, \beta$ and y semicarbazone and thiosemicarbazone 1,3-dithiolanes as radioprotectors. Anticonvulsant activity. European Journal of Medicinal Chemistry 1996, 31, 589-95, http://dx.doi.org/10.1016/0223-5234(96)89554-7.

11. Trotsko, N.; Golus, J.; Kazimierczak, P.; Paneth, A.; Przekora, A.; Ginalska, G. Design, synthesis and antimycobacterial activity of thiazolidine-2,4-dione-based thiosemicarbazone derivatives. Bioorganic Chemistry 2020, 97, http://dx.doi.org/10.1016/j.bioorg.2020.103676.

12. Ribeiro, A.G.; Almeida, S.M.V.; de Oliveira, J.F.; de Souza T.R.C.; dos Santos, K.L.; Albuquerque, A.P. Novel 4-quinoline-thiosemicarbazone derivatives: Synthesis, antiproliferative activity, in vitro and in silico biomacromolecule interaction studies and topoisomerase inhibition. European Journal of Medicinal Chemistry 2019, 182, http://dx.doi.org/10.1016/j.ejmech.2019.111592.

13. Da Silva, P.R.; de Oliveira, J.F.; da Silva, A.L.; Queiroz, C.M.; Feitosa, A.P.S.; Duarte D.M.F.A. Novel indol-3-yl-thiosemicarbazone derivatives: Obtaining, evaluation of in vitro leishmanicidal activity and ultrastructural studies. $\quad$ Chemico-Biological Interactions http://dx.doi.org/10.1016/j.cbi.2019.108899.

14. Sagnou, M.; Mavroidi, B.; Kaminari, A.; Boukos, N.; Pelecanou, M. Novel Isatin Thiosemicarbazone Derivatives as Potent Inhibitors of $\beta$-Amyloid Peptide Aggregation and Toxicity. ACS Chemical Neuroscience 2020, 29, 11, 2266-2276, http://dx.doi.org/10.1021/acschemneuro.0c00208.

15. Hussein, M.A.; Iqbal, M.A.; Umar, M.I.; Haque, R.A.; Guan, T.S. Synthesis, structural elucidation and cytotoxicity of new thiosemicarbazone derivatives. Arabian Journal of Chemistry 2019, 12, 3183-3192, http://dx.doi.org/10.1016/j.arabjc.2015.08.013.

16. Da Silva Filho, F.A.; de Freitas Souza, T.; Ribeiro, A.G.; Alves, J.E.F.; de Oliveira, J.F.; de Lima Souza, T.R.C. Topoisomerase inhibition and albumin interaction studies of acridine-thiosemicarbazone derivatives. International Journal of Biological Macromolecules 2019, 138, 582-589, http://dx.doi.org/10.1016/j.ijbiomac.2019.07.097.

17. Bahojb Noruzi, E.; Shaabani, B.; Geremia, S.; Hickey, N.; Nitti, P.; Kafil, H.S. Synthesis, Crystal Structure, and Biological Activity of a Multidentate Calix[4]arene Ligand Doubly 
Functionalized by 2-Hydroxybenzeledene-Thiosemicarbazone. Molecules 2020, 16, http://dx.doi.org/10.3390/molecules25020370.

18. Siddiqui, E.J.; Azad, I.; Khan, A.R.; Khan, T. Thiosemicarbazone Complexes as Versatile Medicinal Chemistry Agents: A Review. Journal of Drug Delivery and Therapeutics 2019, 9, 689-703.

19. Mendes, E.P.; Goulart, C.M.; Chaves, O.A.; Faiões, V.d.S.; Canto-Carvalho, M.M.; Machado, G.C.; TorresSantos, E.C.; Echevarria, A.Evaluation of Novel Chalcone-Thiosemicarbazones Derivatives as Potential Anti-Leishmania amazonensis Agents and Its HSA Binding Studies. Biomolecules 2019, 23, http://dx.doi.org/10.3390/biom9110643.

20. Pham, V.H.; Phan, T.P.D.; Phan, D.C.; Vu, B.D. Synthesis and Bioactivity of Thiosemicarbazones Containing Adamantane Skeletons. Molecules 2020, 13, http://dx.doi.org/10.3390/molecules25020324.

21. Ishaq, M.; Taslimi, P.; Shafiq, Z.; Khan, S.; Ekhteiari Salmas, R.; Zangeneh, M.M. Synthesis, bioactivity and binding energy calculations of novel 3-ethoxysalicylaldehyde based thiosemicarbazone derivatives. Bioorganic Chemistry 2020, 100, http://dx.doi.org/10.1016/j.bioorg.2020.103924.

22. Klayman, D.L.; Scovill, J.P.; Bartosevich, J.F.; Mason, C.J. 2-Acetylpyridine thiosemicarbazones. 2. N4,N4Disubstituted derivatives as potential antimalarial agents. Journal of Medicinal Chemistry 1979, 22, 13671373, http://dx.doi.org/10.1021/jm00197a017.

23. Pandeya, S.N.; Ponnilavarasan, I.; Pandey, A.; Lakhan, R.; Stables, J.P. Evaluation of p-nitrophenyl substituted semicarbazones for anticonvulsant properties. Die Pharmazie 1999, 54, 923-925.

24. Pandeya, S.N.; Manjula, H.; Stables, J.P. Design of semicarbazones and their bio-isosteric analogues as potential anticonvulsants. Pharmazie 2001, 56, 121-124, http://dx.doi.org/10.1002/chin.200118081.

25. Bharti, N.; Husain, K.; Gonzalez Garza, M.; Cruz-Vega, D.E.; Castro-Garza, J.; Mata-Cardenas, B.D. Synthesis and in vitro antiprotozoal activity of 5-nitrothiophene-2-carboxaldehyde thiosemicarbazone derivatives. Bioorganic \& Medicinal Chemistry Letters 2002, 12, 3475-3478, http://dx.doi.org/10.1016/s0960-894x(02)00703-5.

26. Fahmi, N.; Singh, R.V. Spectroscopic, antifungal, and antibacterial studies of some manganese heterochelates. Journal of the Indian Chemical Society 1996, 73, 257-259, https://doi.org/10.1002/chin.199740303.

27. Anitha, L.; Saritha, S.R.; Layana, S.R.; Nair Lakshmi, C.S.; Hubert Joe, I.; Sudarsanakumar, M.R. Structural studies of 3-[(E)-[(2E)-2-methyl-3-phenylprop-2-en-1-ylidene] amino]-1-phenylthiourea: Combined experimental and computational studies. Journal of Molecular Structure 2019, 1191, 206-217, http://dx.doi.org/10.1016/j.molstruc.2019.04.062.

28. Basri, R.; Khalid, M.; Shafiq, Z.; Tahir, M.S.; Khan, M.U.; Tahir, M.N. Exploration of Chromone-Based Thiosemicarbazone Derivatives: SC-XRD/DFT, Spectral (IR, UV-Vis) Characterization, and Quantum Chemical Analysis. ACS Omega 2020, 10, 30176-30188, http://dx.doi.org/10.1021/acsomega.0c04653.

29. Zhang, H.H.; Qin, C.K.; Chen, Y.; Zhang, Z. Inhibition behaviour of mild steel by three new benzaldehyde thiosemicarbazone derivatives in $0.5 \mathrm{M} \mathrm{H}_{2} \mathrm{SO}_{4}$ : experimental and computational study. Royal Society Open Science 2019, 6, http://dx.doi.org/10.1098/rsos.190192.

30. Vijayan, N.; Ramesh Babu, R.; Gopalakrishnan, R.; Dhanuskodi, S.; Ramasamy, P. Growth and characterization of organic NLO crystals of semicarbazone of acetophenone. Journal of Crystal Growth 2001, 233, 863-867, http://dx.doi.org/10.1016/s0022-0248(01)01628-1.

31. Ramesh Babu, R.; Vijayan, N.; Gopalakrishnan, R.; Ramasamy, P. Growth and characterisation of benzaldehyde semicarbazone (BSC) single crystals. Journal of Crystal Growth2002,240, 545-548, http://dx.doi.org/10.1016/s0022-0248(02)01075-8.

32. Sethuraman, K.; Ramesh Babu, R.; Vijayan, N.; Gopalakrishnan, R.; Ramasamy, P. Synthesis, growth of organic non-linear optical crystal: Semicarbazone of 2-amino-5-chloro-benzophenone (S2A5CB) and its characterisation. Journal of Crystal Growth 2006, 290, 539-543, http://dx.doi.org/10.1016/j.jcrysgro.2006.01.038.

33. Sebastian, S.; Sundaraganesan, N.; Manoharan, S. Molecular structure, spectroscopic studies and first-order molecular hyperpolarizabilities of ferulic acid by density functional study. Spectrochimica Acta Part A: Molecular and Biomolecular Spectroscopy 2009, 74, 312-323, http://dx.doi.org/10.1016/j.saa.2009.06.011.

34. Abraham, J.P.; Joe, I.H.; George, V.; Nielsen, O.F.; Jayakumar, V.S. Vibrational spectroscopic studies on the natural product, columbianadin. Spectrochimica Acta Part A: Molecular and Biomolecular Spectroscopy 2003, 59, 193-199, http://dx.doi.org/10.1016/s1386-1425(02)00148-8.

35. Binoy, J.; Abraham, J.P.; Joe, I.H.; George, V.; Jayakumar, V.S.; Aubard, J. Near-infrared Fourier transform Raman, surface-enhanced Raman scattering and Fourier transform infrared spectra andab initio calculations of the natural product nodakenetin angelate. Journal of Raman Spectroscopy 2005, 36, 63-72, http://dx.doi.org/10.1002/jrs.1272.

36. Arockia Doss, M.; Savithiri, S.; Rajarajan, G.; Thanikachalam, V. Synthesis, spectral, stereochemical and biological evaluation of (E)-2-(3-pentyl-2,6-diarylpiperidin-4-ylidene)-N-phenylhydrazinecarbothioamide derivatives. Phosphorus, Sulfur, and Silicon and the Related Elements 2017, 11, 1264-1270, http://dx.doi.org/10.1080/10426507.2017.1315580. 
37. Frisch, M.J.; Trucks, G.W.; Schlegel, H.B.; Scuseria, G.E.; Robb, M.A.; Cheeseman, J.R.; Scalmani, G.; Barone, V.; Mennucci, B.; Petersson, G.; Nakatsuji, H. Gaussian 09, Revision d. 01, Gaussian. Inc., Wallingford CT, 201. 2009.

38. Jamroz, M.H. Vibrational Energy Distribution Analysis.VEDA 4 Computer Program, Poland, 2004.

39. Glendening, E.D.; Reed, A.E.; Carpenter, J.E.; Weinhold, F. NBO Version 3.1. TCI, University of Wisconsin, Madison, 1998.

40. O’boyle, N.M.; Tenderholt, A.L.; Langner, K.M. cclib: A library for package-independent computational chemistry algorithms. Journal of Computational Chemistry 2008, 29, 839-845, http://dx.doi.org/10.1002/jcc.20823.

41. Thomas, V.L.; McReynolds, A.C.; Shoichet, B.K. Structural Bases for Stability-Function Tradeoffs in Antibiotic Resistance. Journal of Molecular Biology 2010, 396, 47-59, http://dx.doi.org/10.1016/j.jmb.2009.11.005.

42. Bikadi, Z.; Hazai, E. Application of the PM6 semi-empirical method to modeling proteins enhances docking accuracy of AutoDock. Journal of Cheminformatics 2009, 11, http://dx.doi.org/10.1186/1758-2946-1-15.

43. Morris, G.M.; Goodsell, D.S.; Robert, S.; Halliday, Ruth Huey, W.E.; Hart, R.K.; Belew, A.J.; Olsonet. Automated docking using a Lamarckian genetic algorithm and an empirical binding free energy function. Journal. of Computational Chemistry 1998, 19, 1639-1662, https://doi.org/10.1002/(SICI)1096987X(19981115)19:14<1639.

44. Savithiri, S.; Arockia doss, M.; Rajarajan, G.; Thanikachalam, V.; Bharanidharan, S.; Saleem, H. Spectroscopic (FT-IR, FT-Raman) and quantum mechanical studies of 3t-pentyl-2r,6c-diphenylpiperidin-4one thiosemicarbazone. Spectrochimica Acta Part A: Molecular and Biomolecular Spectroscopy 2015, 136, 782-92, http://dx.doi.org/10.1016/j.saa.2014.09.095.

45. Rauhut, G.; Pulay, P. Transferable Scaling Factors for Density Functional Derived Vibrational Force Fields. The Journal of Physical Chemistry 1995, 99, 3093-3100, http://dx.doi.org/10.1021/j100010a019.

46. Dhandapani, A.; Manivarman, S.; Subashchandrabose, S.; Saleem, H. Molecular structure and vibrational analysis on (E)-1-(3-methyl-2,6-diphenyl piperidin-4-ylidene) semicarbazide. Journal of Molecular Structure 2014, 1058, 41-50, http://dx.doi.org/10.1016/j.molstruc.2013.09.052.

47. Krishnakumar, V.; Balachandran, V. Structures and vibrational frequencies of 2-hydroxy-3-methoxy-5nitrobenzaldehyde and 2-methoxy-1-naphthaldehyde based on density functional theory calculations. Spectrochimica Acta Part A: Molecular and Biomolecular Spectroscopy 2006, 63, 464-476, http://dx.doi.org/10.1016/j.saa.2005.05.032.

48. Reed, A.E.; Curtiss, LA.; Weinhold, F. Intermolecular interactions from a natural bond orbital, donoracceptor viewpoint. Chemical Reviews 1988, 88, 899-926, http://dx.doi.org/10.1021/cr00088a005.

49. Silverstein, R.M.; Webster, F.X. Spectroscopic Identification of Organic Compounds.7th ed., Wiley, New York, 2005.

50. Singh, D.K.; Srivastava, S.K.; Ojha, A.K.; Asthana, B.P. Vibrational study of thiophene and its solvation in two polar solvents, DMSO and methanol by Raman spectroscopy combined with ab initio and DFT calculations. Journal of Molecular Structure 2008, 892, 384-391, http://dx.doi.org/10.1016/j.molstruc.2008.06.008.

51. Gussoni, M.; Castiglioni, C.; Ramos, M.N.; Rui, M.; Zerbi, G. Infrared intensities: from intensity parameters to an overall understanding of the spectrum. Journal of Molecular Structure 1990, 224, 445-470, http://dx.doi.org/10.1016/0022-2860(90)87033-t.

52. Geskin, V.M.; Lambert, C.; Brédas, J.L. Origin of High Second- and Third-Order Nonlinear Optical Response in Ammonio/Borato Diphenylpolyene Zwitterions: the Remarkable Role of Polarized Aromatic Groups. Journal of the American Chemical Society 2003, 125, 15651-15658, http://dx.doi.org/10.1021/ja035862p.

53. James, C.; Raj, A.A.; Reghunathan, R.; Jayakumar, V.S.; Joe, I.H. Structural conformation and vibrational spectroscopic studies of 2,6-bis(p-N,N-dimethyl benzylidene)cyclohexanone using density functional theory. Journal of Raman Spectroscopy 2006, 37, 1381-1392, http://dx.doi.org/10.1002/jrs.1554.

54. Murray, J.S.; Sen, K. Molecular Electrostatic Potentials. Concepts and 399 Applications, Elsevier, Amsterdam, 1996.

55. Ott, J.B.; Boerio-Goates, J. Statistical Thermodynamics. Chemical Thermodynamics: Principles and Applications 2000, 497-592, http://dx.doi.org/10.1016/b978-012530990-5/50011-0.

56. Pajouhesh, H.; Lenz, G.R. Medicinal chemical properties of successful central nervous system drugs. NeuroRX 2005, 2, 541-553, http://dx.doi.org/10.1602/neurorx.2.4.541. 